Article

\title{
Timing of Contractional Tectonics in the Miocene Foreland Basin System of the Umbria Pre-Apennines (Italy): An Updated Overview
}

\author{
Francesco Brozzetti ${ }^{1,2}$, Daniele Cirillo ${ }^{1,2, *}$ and Lucina Luchetti ${ }^{3}$ \\ 1 Dipartimento di Scienze Psicologiche, della Salute e del Territorio, Università G. d'Annunzio, \\ via dei Vestini 31, 66100 Chieti, Italy; francesco.brozzetti@unich.it \\ 2 Centro inteRUniversitario per l'analisi SismoTettonica tridimensionale (CRUST), 66100 Chieti Scalo, Italy \\ 3 ARTA-Abruzzo, District of Chieti, Via D. Spezioli 52, 66100 Chieti, Italy; 1.luchetti@artaabruzzo.it \\ * Correspondence: d.cirillo@unich.it; Tel.: +39-0871-355-6389
}

check for updates

Citation: Brozzetti, F.; Cirillo, D.; Luchetti, L. Timing of Contractional Tectonics in the Miocene Foreland Basin System of the Umbria Pre-Apennines (Italy): An Updated Overview. Geosciences 2021, 11, 97. https://doi.org/10.3390/ geosciences 11020097

Academic Editors: Domenico Liotta, Giancarlo Molli, Angelo Cipriani and Jesus Martinez-Frias

Received: 5 January 2021

Accepted: 8 February 2021

Published: 19 February 2021

Publisher's Note: MDPI stays neutral with regard to jurisdictional claims in published maps and institutional affiliations.

Copyright: (c) 2021 by the authors. Licensee MDPI, Basel, Switzerland. This article is an open access article distributed under the terms and conditions of the Creative Commons Attribution (CC BY) license (https:// creativecommons.org/licenses/by/ $4.0 /)$.

\begin{abstract}
A large dataset of lithostratigraphic and biostratigraphic data, concerning the Early-Late Miocene turbidite succession of the Umbria pre-Apennines, is presented and analyzed. The data come from the study of 24 sections that are representative of all the main tectonic units cropping out between the front of the Tuscan allochthon and the Umbria-Marche calcareous chain. The sections have been dated using quantitative calcareous nannofossil biostratigraphy and, wherever possible, they were correlated through key-beds recognition. Such a multidisciplinary approach allowed us to reconstruct the evolution of the Umbria foredeep over time and to unveil the chronology of compressive deformations by defining: (i) the onset of the foredeep stage in each structural unit, (ii) the age of depocenter-shifting from a unit to the adjacent one, (iii) the progressive deactivation of the western sector of the foredeep due to the emplacement of allochthon units, and (iv) the internal subdivisions of the basin due to the presence of foreland ramp faults or thrust-related structures. A further original outcome of our study is having brought to light the Late Burdigalian "out-of-sequence" reactivation of the Tuscan allochthon which bounded westward the foredeep, and the subsequent protracted period of tectonic stasis that preceded the deformations of the Umbrian parautochthon.
\end{abstract}

Keywords: Umbria pre-Apennines; foreland basin systems evolution; timing of contractional tectonics; biostratigraphic constraints to foredeep deposition

\section{Introduction}

It is widely recognized that, in a foreland basin system, the spatial-temporal distribution of sedimentary processes reflects the tectonic deformations which drove its structuring [1,2]. Such a close link between the evolution of the chain and the depositional events that occurred in the foredeep and the associated satellite basins is well documented in any stage of the Apennines orogenic system [3-7].

During their eastward migration, the foreland basin systems of the Apennines included the following tectono-sedimentary zones [1,2,8]: (i) piggyback or thrust-top basins, characterized by continental and shallow marine deposition occurred unconformably above older foredeep successions, (ii) foredeep basin, a high-subsidence basin hosting deep-water turbidites lying in slight unconformity on pre-orogenic successions, and (iii) forebulge sector, where sedimentation of hemipelagic ramp-mud [9] occurred, in substantial conformity, on the foreland monocline.

We tried to reconstruct the nature and timing of the tectonic events which affected the Umbria pre-Apennines based on a detailed litho- and bio-stratigraphic analysis of the sin-tectonic successions outcropping in the sections shown in Figure 1, which have been selected taking into account also their present structural setting. 


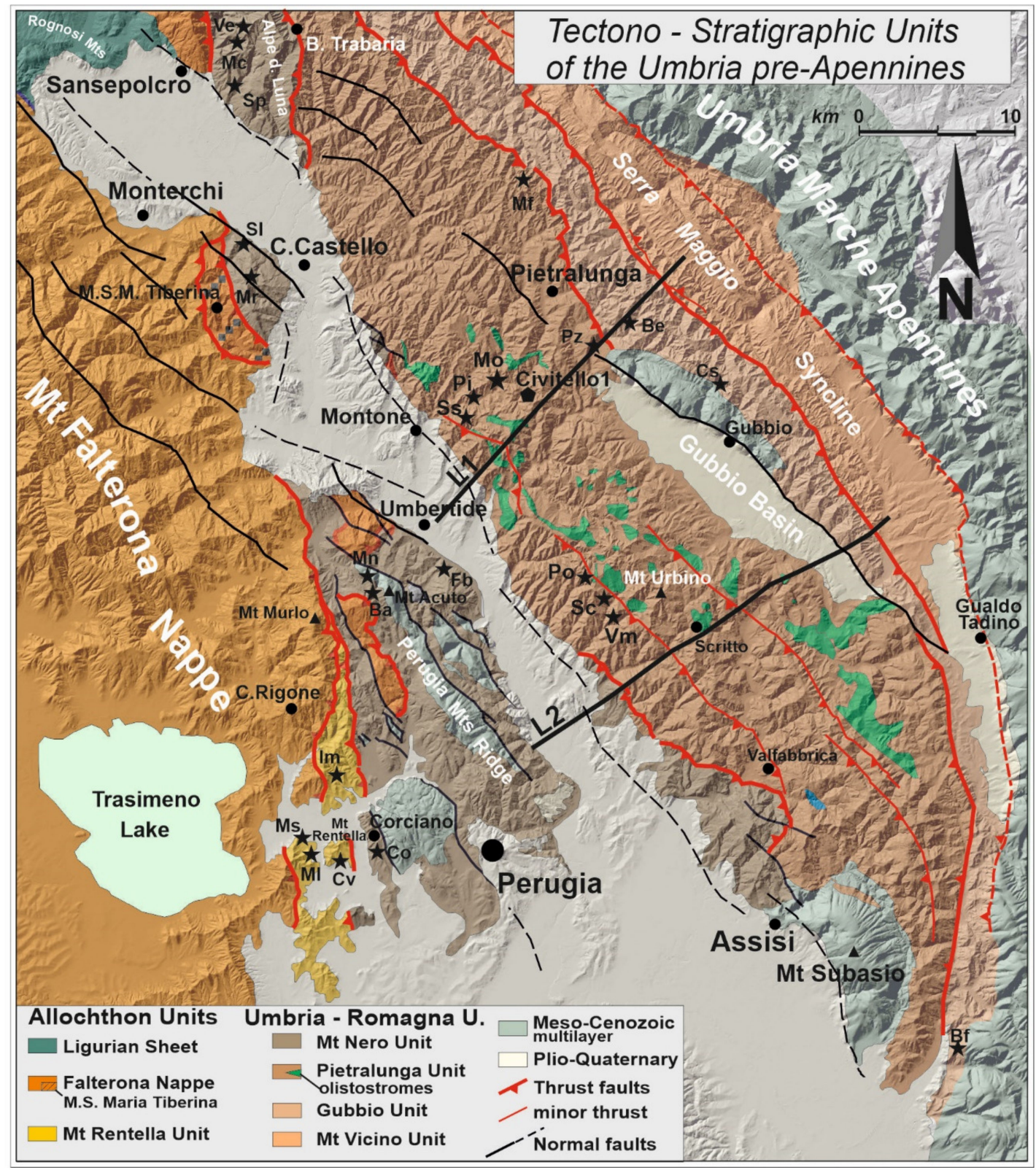

Figure 1. Structural Geological scheme of the study area showing the main tectono-stratigraphic units in which the Early-Middle Miocene Marnoso Arenacea basin is presently split according to the data reported in [10-16]. Asterisks and acronyms locate the studied sections as explained in the following: REN Unit: Ml = I Molini, Ms = Monte Sperello, $\mathrm{Cv}=$ Castelvieto, Im = Il Molino; Mt Nero Unit: Ba = Balconcelli, Co = Corciano, Mn = Monestevole, Fb = Fosso della Badia, $\mathrm{Sp}=$ Case Spertaglia, Mc = Monte Casale, Ve = Vesina; M. S. Maria Tiberina area: Sl = San Lorenzo, Mr = Monte Cedrone; Pietralunga Unit: $\mathrm{Pz}=$ Piazze, $\mathrm{Sc}=$ Santa Cecilia, $\mathrm{Po}=$ Portole, $\mathrm{Vm}=$ Valmarcolone, $\mathrm{Ss}=$ Sassarone, $\mathrm{Pt}=\mathrm{Pietralata}$, Mo = Moravola; Gubbio Unit: Cs = Contessa, Be = Bavelle; Mf = Madonna dei 5 Faggi, Bf = Belfiore.

The Umbria pre-Apennine is a $\sim 40 \mathrm{~km}$-wide belt delimited to the west by the front of the Tuscan Falterona nappe and to the east by the inner border of the Umbria-Marche calcareous chain (Figure 1) [10-14].

Its shallow structure consists mainly of an east-verging imbricate fan formed by the stacking of Early to Late Miocene successions of turbidites and hemipelagites. Within the pre-Apennine, the Meso-Cenozoic Umbria-Marche multilayer crops out only in correspondence of narrow culminations located in the Perugia Mts ridge (west of the Tiber river) and in the Gubbio and Mt Subasio doubly plunging anticlines (eastern Umbria, Figure 1). 
The major thrust-sheets correspond to regional tectono-stratigraphic units referred to, in the literature, as Mt Rentella, Mt Nero, Pietralunga, Gubbio, and Mt Vicino units, from west to east (Figure 1) [11-15]. The turbidite succession characterizing each one of these units differs from the neighboring ones as regards the age of the top of the basal ramp-mud, the time interval during which the turbidite sedimentation took place, the feeding areas of the gravity flows, and their dispersal pattern [15-20].

A clear eastward-younging trend is documented by the ages through which each unit evolved, from the foreland to the foredeep stage, and was progressively incorporated into the chain.

In fact, as highlighted by previous biostratigraphic data, thrusting rejuvenated from the Late Burdigalian, in the Mt Rentella Unit, to the Early-Late Tortonian, in the easterner Gubbio ad Mt Vicino units [15-17,21-23].

The various tectonic stages which involved the basin were marked by major changes in local and regional stratigraphy, in the sedimentary rates, in turbidite facies, and arenite composition.

An additional factor that had a significant influence on foredeep sedimentation and its duration over time was the emplacement, on the western border of the basin, of allochthon terrains of Tuscan and Ligurian pertinence. The latter became, for a long period, the source areas of transversal sedimentary inputs and of regional-scale olistostromic bodies that were embedded at various levels within the Marnoso Arenacea Fm [17,19,24,25].

In such a general picture, an overall and updated synthesis of the depositional architecture and the structural setting of the pre-Apennine foreland basin is still lacking, and the timing of deformation has been defined only in broad terms, except for restricted sectors.

The first objective of our work is therefore to revise the stratigraphy of the Miocene successions at the scale of the entire basin, defining the vertical and lateral relationships among the different units.

Once the stratigraphic framework has been reconstructed, we highlight those depositional events that were driven by tectonics and are useful to define a high-resolution timing of the deformational events that affected the foredeep, from its onset to the complete accretion into the chain.

In particular, an issue that was not previously explored in-depth, and deserves to be addressed, is the influence exerted on sedimentation by the concurrent activity of contractional structures and foreland ramp faults, both displacing, during the Middle-Late Miocene, the Meso-Cenozoic carbonate substratum [7,21,22].

We have pursued the aforementioned goals by analyzing, reviewing, and correlating a total of 24 stratigraphic sections representative of the entire foreland basin system of the Umbria pre-Apennine, most of which unpublished. The sections, which have been studied through quantitative nannofossil biostratigraphy, are located in the six following key-areas; from west to east, these are (Figure 1): (1) Mt Rentella, (2) Perugia Mts ridge, (3) Alpe della Luna, (4) M. S. Maria Tiberina, (5) Pietralunga-Mt Urbino ridge and (6) Gubbio-Serra Maggio.

This paper aims to provide an overview of all turbidite successions referred, in the literature, to the Umbrian domain, giving useful chronological constraints to future research on the tectonics and geodynamics of the Tyrrhenian-Apennines system, focusing on the Miocene deformational stages.

We are also confident that our work can be explanatory of a methodological approach, based on the intimate integration of stratigraphy and tectonics, that we consider highly effective in the study of foreland basin systems.

\section{Materials and Methods}

\subsection{Physical Stratigraphy}

We started from an accurate revision of a huge bulk of unpublished lithostratigraphic data, acquired during original research surveys and the CARG project 289-Città di Castello Sheet of the Carta Geologica d'Italia [20]. 
These data, which had already been calibrated by nannofossils biostratigraphy [26], were subsequently homogenized with the datasets reported in previous works dealing with the tectono-stratigraphic setting of the Mt Rentella [15], M. S. Maria Tiberina [7,21,27], and Mt Nero [18] units. Further stratigraphic sections have been recently studied in sectors of the pre-Apennine where, in the course of this study, the need for further integrative data emerged.

An accurate physical-stratigraphic analysis was carried out on all the sections, to distinguish the stratigraphic units of various ranks within the Miocene successions, such as formations, members, facies associations, and key beds.

Logging was carried out at a 1:50 scale factor, which allowed us to collect and describe all the major sedimentary features characterizing the different types of strata and their composition and provenance, and ultimately formulate hypotheses on the depositional mechanisms and the types of causative gravity flows.

An expeditious compositional determination was also performed by comparing hand specimens with the petrofacies described in several type-sections of the high Tiber Valley by [28-31]. These determinations, integrated with facies analysis (based on the classification scheme defined by [32]) and paleocurrent measurements, allowed us to distinguish the arenites of alpine provenance, generally characterized by fine grain size, distal facies, and low thickness, from the deposits originated by transversal supply [25], which were fed from piggyback basins lying above the Apennines front.

\subsection{Biostratigraphy}

During stratigraphic logging, the sections were sampled for micropaleontological purposes.

The marly samples collected for the biostratigraphic analysis were prepared as smear slides according to the procedures indicated by [33-35] and subsequently studied under a polarizing optical microscope at $1000 \times$ with both parallel and crossed nicols.

The microscopic analyses of nannofossil assemblages were referred to the biozonations schemes proposed by [35-37] for the Late Oligocene and Early-Middle Miocene of the Mediterranean domain (Figure 2).

The adopted schemes still show a better resolution either with respect to the "standard" ones [38,39] or to the recent upgrades of the tertiary nannofossil biostratigraphy [40,41], which have been mainly defined based on ocean bio-events recognized on a global scale. Other updated schemes of the Miocene Mediterranean nannofossils biostratigraphy are available but, having reviewed only some certain time-intervals (the Burdigalian stage in [42] and the Langhian stage in [43]), their use would lead to some problems of chronostratigraphic correlations with the biozonation proposed by [35-37].

The latter works, including the entire Miocene, are therefore still to be preferred for the study of stratigraphic successions that cover a large part of this epoch.

In each sample, the identification of marker species has been integrated by quantitative analysis, carried out following the methodologies developed by several authors [35,44].

It consists of two kinds of counting: the first counts the species percentages within a population of 300 specimens of the whole assemblage; the second is carried out only for the most significant species whose percentage is determined in comparison with a fixed number of coccoliths pertaining to the same genus (f.i. counting of S. heteromorphus within 100 sphenoliths).

The application of quantitative methodologies has also allowed the aforesaid authors to establish new bio-horizons based on variations in the abundance of some marker species, such as the First Common Occurrence (FCO), the Beginning of the Paracme (PB), and the End of the Paracme (PE) of Sphenolithus heteromorphus.

Finally, in the case of the individuals belonging to the genus Reticulofenestra-which, although having been studied in depth [34,45-49], still present classification problems-a biometric approach has been applied. The latter led to referring to Reticulofenestra pseudoumbilicus individuals with size $>7[35,37,44,50]$ and to distinguish them from those 
characterized by a smaller size (which have been, in turn, shared in two classes, respectively characterized by size $<6 \mu \mathrm{m}$ and $>6 \mu \mathrm{m}$ ).

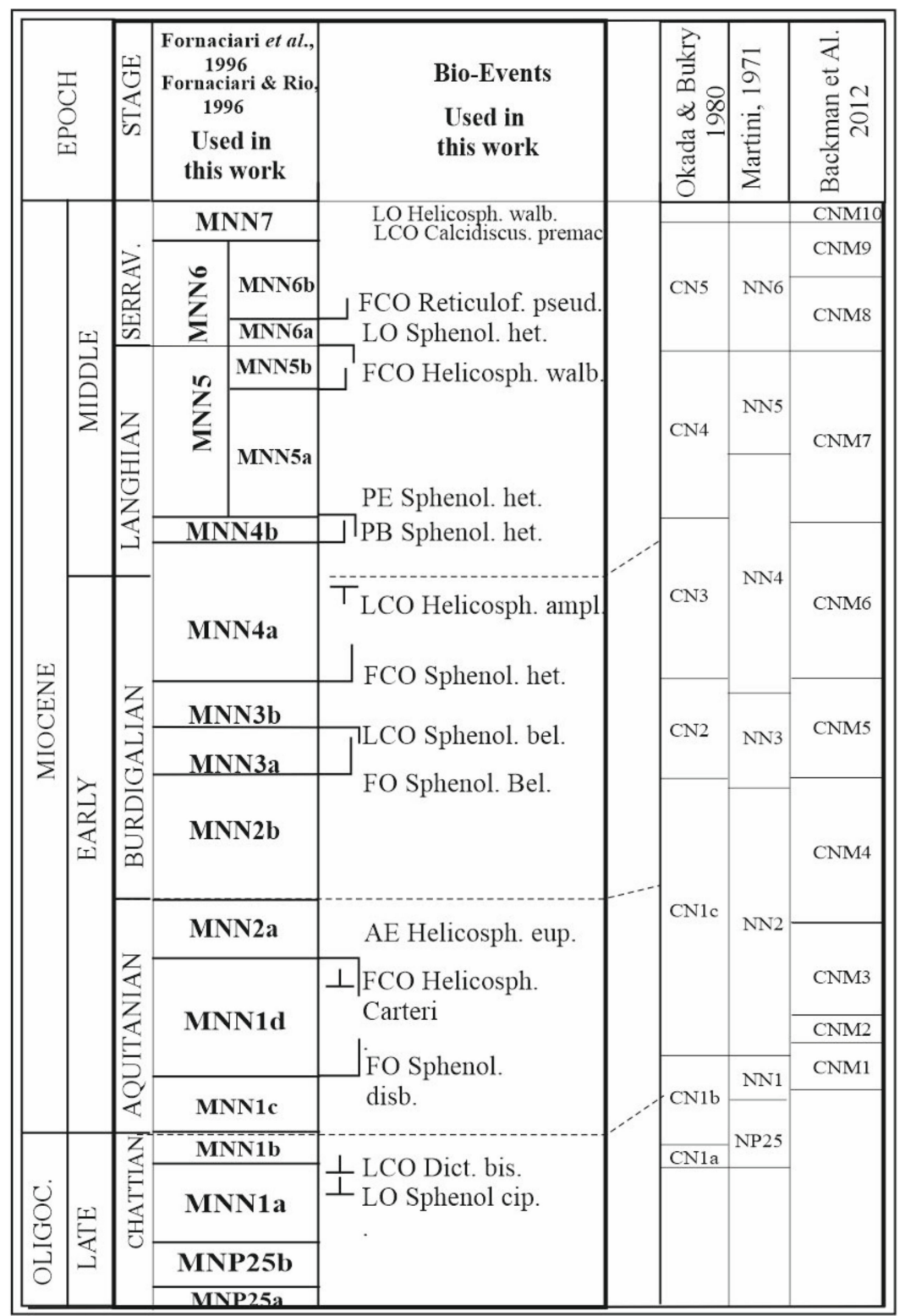

Figure 2. Biostratigraphic scheme for the Upper Oligocene-Middle Miocene interval. The scheme correlates the nannofossils biozonations proposed by [35,37], used in this work, with the Standard ones by [38,39], recently updated by [41]. The scheme is also integrated (bold rectangle) with the main bio-event characterizing the Mediterranean area.

The variation in abundance of the marker species, within each succession, was highlighted by plotting the relative distribution diagrams alongside the corresponding lithostratigraphic Log.

\subsection{Field Geology}

A large part of the fieldwork was carried out in the past years using the traditional geological mapping techniques. These former surveys, however, were recently revised and integrated with digital surveys and new data collection, aided by an Apple iPad-Pro in which a dedicated mapping software, whose details are given in the following section, was installed. 
Due to the considerable extension of the study area, most of the structural survey was performed in selected key outcrops to characterize the major tectonic contacts and the spatial relationships between the Tectono-Stratigraphic units, synthesized in Figure 1.

Two commercial seismic lines provided by [51], hereinafter referred to as L1 and L2 (traces in Figure 1), have been interpreted to assess the present thickness of Miocene foredeep deposits and detect the geometry of the contractional deformations. The seismic interpretation through Move software was performed on both the aforesaid lines.

\section{An Overview on the Tectono-Stratigraphic Units of the Umbria Pre-Apennines}

\subsection{Mt Rentella Unit}

The Mt Rentella unit (REN) [15] crops out in a narrow $\sim$ NS striking belt, tectonically sandwiched between the Tuscan Falterona Nappe, to the west, and the Marnoso Arenacea Fm of the Mt Nero Unit, to the east. Its peculiar stratigraphy justifies its classification as an independent tectono-stratigraphic unit derived from a paleogeographic domain located in an intermediate position between the two aforementioned units.

In the type locality (sections Im, Ms, Ml, and Cv, Figure 1), the REN includes, from the bottom, the polychromic marls of Mt Rentella, the cherty marls of Mt Sperello, and the Castelvieto turbiditic sandstones (also referred to as La Montagnaccia Fm by [13,52-55]). The nannofossil assemblages [15] show that the polychromic marls are referable to the MNP25b-MNN1d biozones (Late Oligocene-Aquitanian), the cherty-marly interval to the MNN1d-MNN2a biozones (approximating the Aquitanian-Burdigalian boundary), and the turbidite succession deposited during the MNN2a-MNN2b biozones (Early Burdigalian) $[15,53,54]$. A bio-chronostratigraphic correlation table, showing the overall stratigraphy, reconstructed "mending" the portions of the REN succession logged in four reference sections $(\mathrm{I}$ Molini $=\mathrm{Ml}$, Monte Sperello $=\mathrm{Ms}$, Castelvieto $=\mathrm{Cv}$, and Il Molino $=\mathrm{Im}$, location in Figure 1) is provided in Figure S1 (Supplementary Materials). Based on these results, the Mt Rentella sequence cannot be biostratigraphically correlated either to the topmost part of the Falterona Nappe, which is older [52-57], or to the outcropping turbiditic sequence of the Umbria domain, which is younger $[7,17,18]$.

As regards the compositional data concerning the fine-grained lithic fragments, the arenites characterizing the turbidite succession of the REN differ sensibly from the Macigno sandstones, whereas they are comparable with some Alpine-fed beds of the Marnoso Arenacea Fm [31-51,58,59].

The reported litho- and bio-stratigraphic constraints suggest that the REN represents a tectonic slice originated by the innermost marginal sector of the Umbria domain which, during the Chattian and most of the Aquitanian, was located in the peripheral bulge of the Tuscan foredeep, which will never be reached later on, by the deposition of the Macigno turbidites. Such a hypothesis would account for the remarkable facies affinity between the polychromic marls of Mt Rentella and the "Scisti Policromi" Auctt. occurring at the top of the Tuscan Scaglia, the former being characterized by a larger content of calcium carbonate.

In the study area, the succession of the REN is rootless, being detached on the polychromic marls and tectonically superimposed to the Marnoso Arenacea Fm of the Mt Nero unit. For this reason, its stratigraphic passage to the original carbonate substrate was nowhere observed.

According to [15], this substrate would correspond to the succession cropping out in the Mt Peglia-Mt Piatto ridge (south-western Umbria), characterized by an "Umbria type" facies but showing some affinities with the Tuscan terms, during the Oligocene-Early Miocene [60].

\subsection{Units Derived from the Marnoso Arenacea Foredeep}

The Marnoso Arenacea foredeep basin [24,61,62] developed, since Early-Middle Burdigalian times, in front of a tectonic pile made of the REN unit and the overlying Falterona Nappe. The turbidite deposition lasted, within this basin, until the Late Miocene, when it was tectonized and completely incorporated within the Umbria pre-Apennines. 
After the seminal work of [10], several studies contributed to identify, within the deformed Marnoso Arenacea of the Umbria area (MAR hereinafter), a number NW-SE trending sectors characterized by significant stratigraphic differences and diachronic tectonic evolutions [7,11-18,21,28,29,61-66].

These sectors, delimited by regional-scale thrust surfaces, can be considered as tectonostratigraphic units, namely thrust sheets whose internal stratigraphy is substantially homogeneous but showing significant differences compared to the adjacent ones (Figure 3). In the present work, for reasons of conciseness, the term "Unit" is used with the meaning above.

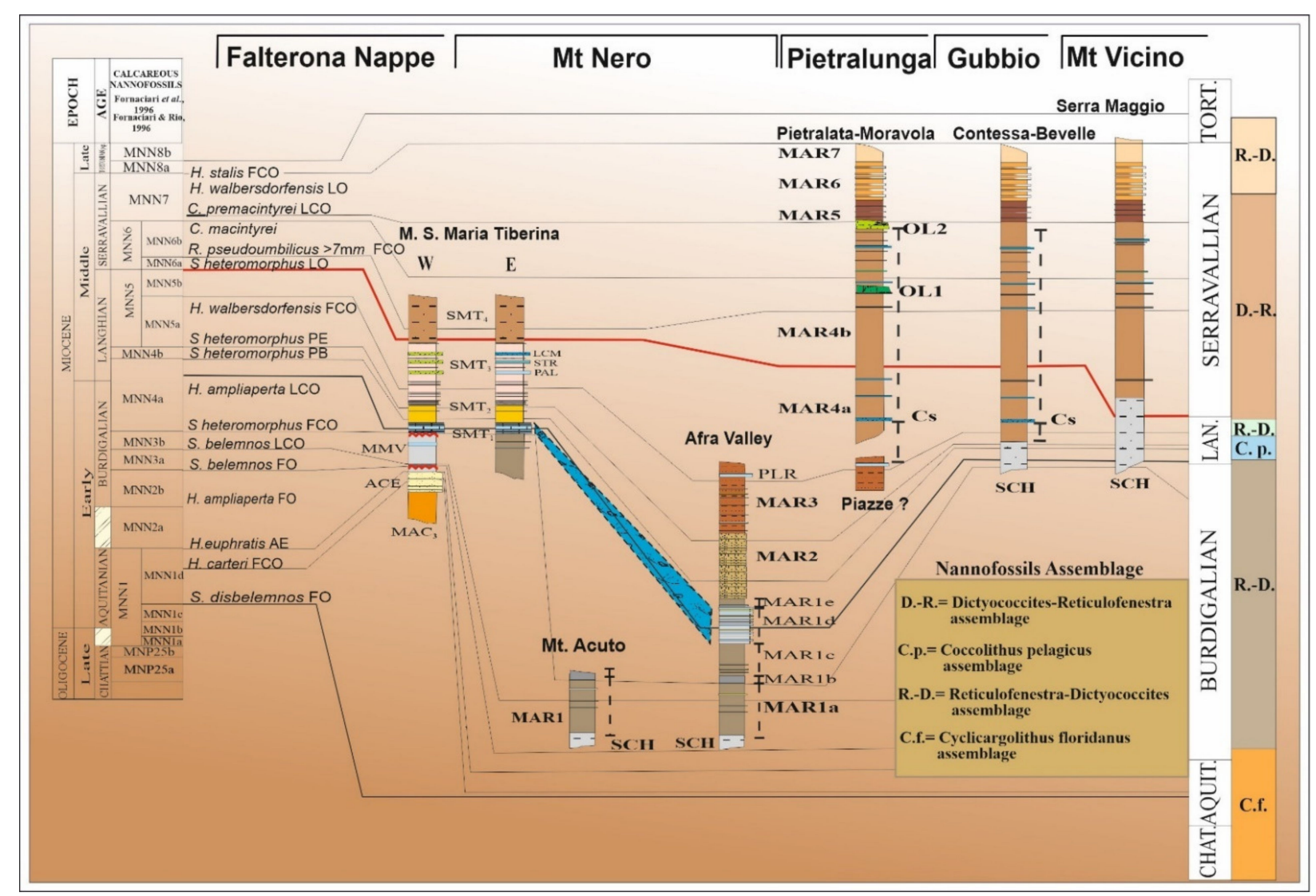

Figure 3. Comprehensive stratigraphic scheme of the Umbria pre-Apennine Marnoso Arenacea succession cropping out East of the Falterona Nappe and Mt Rentella frontal thrusts to the inner side of the carbonate chain. The columns represent, to all effects, composite Logs obtained by correlating the studied sections, located in Figure 1.

Within each Unit, sedimentation was mainly controlled by the following tectonic processes: (a) flexural retreat of the regional monocline, which caused the system depocenterramp-peripheral bulge of the foredeep to shift eastward [9], (b) progressive emplacement, along the western border of the foredeep, of allochthon units of Tuscan and Ligurian pertinence $[7,15]$, (c) activity of foreland ramp synsedimentary normal faults, and (d) nucleation and progressive growth of compressional structures in the carbonatic substratum of the basin.

Ultimately, the MAR Units derive from pre-contractional chain-parallel isopic zones which differed from each other in what concerns the age of onset of turbiditic sedimentation, its duration over time, and, partly, the sedimentological and compositional characteristics of the beds.

Based on the aforesaid criteria, in the Umbria pre-Apennines, the Mt Nero, Pietralunga, Gubbio, and Mt Vicino Units have been recognized, from west to east (Figures 1, 3 and 4). Their sedimentary and tectonic evolution is synthetically described below. 


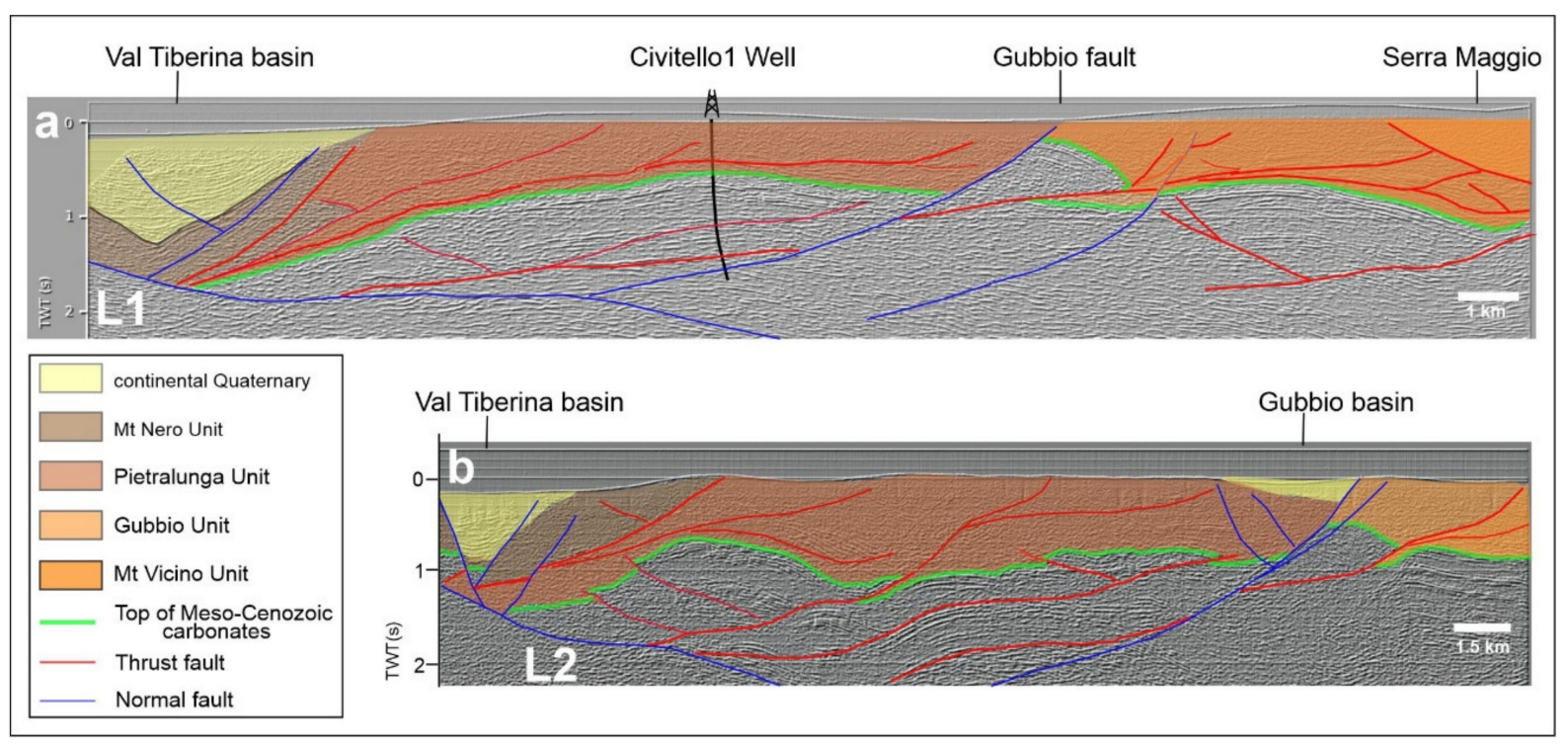

Figure 4. Interpreted seismic reflection profiles crossing the deformed Marnoso Arenacea, cropping out between the Tiber valley Quaternary graben and the Apennine calcareous chain; $(\mathbf{a})=$ line L1, $(\mathbf{b})=$ line L2 whose traces are shown in Figure 1. Both the "clean" sections are taken from [51] and here re-interpreted in light of the different aims of our work.

\subsubsection{Mt Nero-Unit}

The Mt Nero Unit includes the more internal successions of the MAR, which originated from the Burdigalian-Langhian depocenter of the Umbria foredeep.

From a tectonic point of view, it belongs to the so-called "internal Umbria Romagna parautochthon" [16], which overrides, along a NW-SE trending thrust fault (Bocca Trabaria thrust), the Pietralunga Unit (Figure 1). Clear exposures of the Mt Nero succession can be observed in the Perugia Mts ridge and on the east sides of the northern Valtiberina, where these successions are also referred to as "Alpe della Luna sequence" (Figure 1).

In previous studies, the lithostratigraphy of the Mt Nero succession had been pointed out for both these areas $[17,28,64,65,67]$, but an updated biostratigraphic calibration was defined only during the recent survey of the 289-Città di Castello Sheet of the Carta Geologica d'Italia [20].

In the Alpe della Luna (Figure 1), the stratigraphic sections are quite continuous and, despite some minor gaps, allow for an investigation of the entire succession lying over the Schlier Fm (Figure 3 and Figure S2). In this area, the MAR, from the bottom, is composed by:

(1) a pelitic-arenitic member ( $\mathrm{mr}$ hereinafter), named as MAR1 or Case Spertaglia mr, extending from the MNN3a to the MNN4b nannofossil biozones; it includes (section Spertaglia $=S p$ ) a lower facies characterized by prevalent thin-bedded alpine-supplied turbidites (fine-grained and mica-rich arenites with NW-SE provenances) and an upper facies dominated by thick-bedded transversally-supplied calcarenites and hybrid arenites, containing coarse-grained lithoclasts of Ligurian origin;

(2) an intermediate massive sandstone member, consisting of arkosic transversal-supplied turbidites referred to as MAR2 or Mt Casale mr, developing across the MNN4b to MNN5a biozones (section Monte Casale = Mc);

(3) an upper pelitic-arenaceous member referred to as MAR3 or Vesina $\mathrm{mr}$, straddling the MN5a-MN5b biozones, mainly consisting of alpine-supplied turbidites showing sub-arkosic composition and laminated tractive intervals (Section Vesina $=\mathrm{Ve}$ ); in the uppermost part of this member, the Poggio La Rocca Mega-bed, a coarsegrained calcarenite, which in the past was incorrectly correlated with the Contessa key-bed [28], occurs. 
In the Perugia Mts ridge, where only the two lower mrs of the MAR crop out, the exposures are discontinuous (Figure 1) and separated by a thrust fault which splits the Mt Nero Unit in two distinct thrust sheets, the western or "Mt Acuto" and the eastern or "Mt Corona" tectonic elements. Consequently, the stratigraphic continuity between the two members cannot be directly observed.

The Mt Acuto element consists only of the pelitic-arenaceous lower facies of the MAR1 $\mathrm{mr}$, referable to the MNN3a-MNN4a biozones (sections Balconcelli = Ba, Corciano = Co and Monestevole = Mn, location in Figure 1, stratigraphy in Figure 3 and Figure S2) [18].

The Mt Corona element is instead characterized, at the surface, by the higher interval of the MAR1 mr and part of the MAR2 mr (Section Fosso della Badia = Fb in Figure 1), which, consistently with the section of Mt Casale, have been dated to the Middle-Late Langhian, MNN4b-MNN5a zones [18].

Synthesizing, within the entire Mt Nero Unit, the beginning of the MAR sedimentation (i.e., the onset of the foredeep stage s.s.) can be referred to the upper part of the Early Burdigalian, being the lowest passage to the Schlier Fm identifiable in the MNN3a biozone.

Conversely, the top of the Fm is markedly diachronic because it corresponds, in the western sector (Mt Acuto) to the intermediate portion of the MAR1 (MNN4a subzone, Late Burdigalian) and in the eastern sector (Alpe della Luna) to the uppermost MAR3 (MNN5b, Late Langhian; Figure S2).

The Mt Acuto succession does not include the higher part of the MAR1 because, in the internal sector of the foredeep, the MAR sedimentation was interrupted, during the MNN4a biozone, by the emplacement of the Falterona Nappe.

East of the leading edge of the Falterona Nappe, in the easternmost portion of the Mt Nero Unit, the topmost MAR1 $\mathrm{mr}$ and the following MAR2 (Late Burdigalian-Early Langhian) and MAR3 (Early-Late Langhian) members continued regularly to deposit, at least up to the top of the MNN5a biozone.

\subsubsection{The Monte Santa Maria Tiberina Succession}

The M. S. Maria Tiberina area has long been considered a crucial area to investigate the connection between the stratigraphic evolution of the Marnoso Arenacea Fm and the progressive emplacement of the Falterona Nappe along the western boundary of the foredeep.

Conflicting interpretations were formulated in the past on the outcropping Miocene succession, which has recently been re-named as M. S. Maria Tiberina Fm (SMT) in the 239-Città di Castello Sheet of the Carta Geologica d'Italia [30].

The stratigraphic reconstructions formulated by $[7,21,30]$, based on robust biostratigraphic constraints, solved the debate between "autochthonist" [28,68] and "allochtonist" $[10,11]$ interpretations, showing the SMT to have sedimented upon two different substrates, that are the Falterona Nappe and its semi-allochthon cover, in the internal sector, and the lower part of the Marnoso Arenacea Fm (MAR1 mr), in the external one (Figure S3).

More precisely: (i) to the West, the SMT Fm deposited unconformably over the Vicchio Marls of the Late Burdigalian age (MMN4a nannofossil subzone) and, after that, the Falterona Nappe was thrusted upon the inner side of the Umbria foredeep; (ii) in the intermediate zone (Gioiello syncline), the SMT covered the Nappe front and sealed it; and (iii) in the external sector (Mt Cedrone-Uppiano, Section Mr, in Figure 1), the SMT Fm deposited conformably on the Marnoso Arenacea MAR1 mr, whose topmost beds also show a Late Burdigalian age (MNN4a subzone) (Figure S3).

The integrated stratigraphic analysis of the SMT Fm (Section S1 in Figure 1) provides additional information about the timing of the former contractional phases affecting the succession of the Umbria domain.

In fact, the distribution of benthic foraminiferal taxa in the intermediate-to-upper part of this Fm clearly points to a shallowing upward trend of the paleodepth [27] during the Early Serravallian (the boundary between the MNN5b-MNN6a biozones). 
This marked change, preluding the end of SMT sedimentation and also the emplacement of a minor olistostromic body, topping the formation [30], can be related to the growth of incipient anticlines involving the underlying carbonate multilayer of the Mt Nero Unit.

According to this interpretation, the contractional tectonics affected the western Umbria domain from the Middle-Late Serravallian, leading to the thrusting and folding of the MAR and the re-folding of the overlying Falterona Nappe front.

\subsubsection{Pietralunga Unit}

The Pietralunga Unit consists of a succession of turbidites and hemipelagites of Middle Langhian-Late Serravallian age $[12,16]$ deformed by east-verging folds and minor thrusts (Figures 1 and 3).

Its structural arrangement and the thickness of its succession can be well appreciated in two SW-NE striking commercial seismic lines, published by [51], that cross nearly the entire Umbria-pre-Apennines, from the internal contact with the Mt Nero Unit as far as the Gubbio Normal Fault to the East (Figure 4, traces in Figure 1).

Although these profiles have been acquired for deeper targets, deformations affecting the Pietralunga Marnoso Arenacea MAR with the adjacent Mt Nero (to the west) and Gubbio (to the East) Units.

The proposed interpretations allow us to refer the Pietralunga Unit to an imbricate fan, detached on the top of the Meso-Cenozoic carbonates, in which each splay thrust branches upward, in-sequence, from the basal sole thrust.

Nevertheless, some faults seem to penetrate the carbonates, in correspondence with the major structures of Perugia Mts and Gubbio, refolding the overhanging shallow thrust.

In the intermediate part of the L2 line, in a sector unaffected by significant thrust and tectonic doubling, the top of the Meso-Cenozoic carbonates is located at a pseudo-depth of $\sim 1 \mathrm{~s}$ TWT, which, assuming a $\mathrm{v}=4.0 \mathrm{~km} / \mathrm{s}$ seismic velocity [51], provides, for the Miocene succession including the Bisciaro, Schlier, and MAR Fms, a maximum thickness of $\sim 2000 \mathrm{~m}$.

Within the Pietralunga Unit, the age of the basal passage of the turbidites to the Schlier Fm is undetermined, as well as the latero-vertical stratigraphic relationships with the Mt Nero succession, because the lower part of the Unit is buried, and the occurrence, below it, of the MAR1-MAR3 members is uncertain.

The presence of Early Langhian terms, possibly with reduced thickness compared to the western Umbria succession, is suggested by some limited outcrops of a peliticarenaceous succession containing a $7 \mathrm{~m}$-thick calcarenite, sampled in the Piazza area (5 km SE of Pietralunga). This section (Pz in Figure 1) has been tentatively related, in age and composition, with the topmost MAR3 of the Mt Nero Unit including the Poggio La Rocca marker bed (Figures 1 and 3).

The Pietralunga succession shows an outcropping thickness $>1000 \mathrm{~m}$ and, based on the facies analysis, can be divided into four members, hereinafter referred to as MAR4-MAR7.

The $\sim 750 \mathrm{~m}$-thick MAR $4 \mathrm{mr}$ spans in age from the highest part of the MNN5b to the topmost MNN6b nannofossil biozones (Late Langhian-Middle Serravallian) according to [26] and our unpublished data (Figure S4), whereas all the remaining MAR5-7 mrs fall within the MNN7 biozone of the Late Serravallian age.

The overall stratigraphic reconstruction of this member was carried out by correlating eight sections (Vm, Sc, Po, Pz, Ss, Pi, Mo, and Mf, full names and location in Figure 1), that have been logged and analyzed from the litho- and bio-stratigraphic points of view.

The MAR4 $\mathrm{mr}$ is mainly characterized by the typical association of marls, arenite layers, and scattered media to thick-bedded calcarenites and hybrid arenites, with a predominant A/P ratio varying from $<1$ to $<<1$.

Despite an apparent monotonous facies, this member embodies several outstanding layers, including the well-known Contessa mega-bed, the "Colombine" calcarenites (occurring above the Contessa bed $[25,66]$ ) and some very thick and laterally continuous arenite and hybrid arenite beds, useful as key-layers for both geological mapping and basin analysis purposes (Figures S4 and S5 and detailed stratigraphy in [26]). 
As aforesaid, the upper part of the Pietralunga succession is characterized by three further members, all of them falling in the MNN7 biozone, Late Serravallian in age.

The MAR5 $\mathrm{mr}$ corresponds to a quite thin (nearly $150 \mathrm{~m}$ ) pelitic-arenaceous interval, characterized by thin-bedded fine-grained alpine-supplied arenites including some slump episodes.

The passage to the MAR6 $\mathrm{mr}$ is marked by a sharp increase in bed thickness (thick to very thick beds with an arenitic portion up to $8 \mathrm{~m}$ ) and by the complete absence of calcarenite layers.

Finally, the MAR7 mr consists mainly of a pelitic-arenaceous facies association, characterized by a thinning-upward trend and a gradually decreasing $\mathrm{A} / \mathrm{P}$ ratio, until the complete disappearance of the arenite beds.

The upper part of the MAR4 $\mathrm{mr}$ contains at least two large episodes of submarine sliding $[12,24,25,66]$, the lower of which, referred to as "Lame-Castiglione olistostrome", occurs nearly $600 \mathrm{~m}$ above the Contessa bed [66], whereas the uppermost one, or "San Faustino-Scritto olistostrome", is located at least another $400 \mathrm{~m}$ above the former (Figure 3 and Figure S4).

The two olistostromes consist of wide lenses of chaotic materials within which disrupted rock fragments of different origin and size (up to decametric strata-fragments) are scattered in a polychromic sandy-clayey, and locally scaly, matrix. These lithotypes are derived from the Tuscan succession (Scaglia Toscana, jaspers, Triassic gypsum, and anhydrites) and from the Liguride units (Alberese and Palombini shales).

Generally, a thick interval, with a few meters, characterized by slumped intraformational materials, occurs at the base of both the olistostromes.

In the southern part of the study area the upper olistostrome consists of a quite continuous and undamaged stack of strata ("Scritto Limestones", according to [17,24]) which should be correlated with the sub-Ligurian Canetolo succession and the Ligurian units [17]. This attribution implies that, during the Middle Serravallian, the Apennine allochthon had reached the frontal part of the Falterona Nappe.

The detailed lithostratigraphy of the sections studied within the Pietralunga Unit exceeds the objectives of this work.

Anyhow, a composite Log, synthesizing the reconstructed stratigraphy of the entire Unit and showing the occurrence and position of the significant key layers, used for horizontal correlations, is provided in Figure S4.

For a more detailed description of all the sections mapped in Figure 1, the reader is sent back to the original work by [26].

\subsubsection{Gubbio Unit}

The Marnoso Arenacea of the Gubbio Unit overlies the Meso-Cenozoic multilayer of the homonym anticline in eastern Umbria $[12,42,69]$.

In the reference sections of the Contessa Road and Bevelle (Cs and Be, in Figure 1), the Late Langhian-Serravallian succession, from the Contessa mega-bed (MNN5b biozone) upward [26], is well correlated with the Pietralunga one, in what concerns the dominant facies and the occurrence of the major key-beds (compare Figures S4 and S5).

Conversely, in the aforesaid sections, the age of the basal stratigraphic passage to the Schlier Fm differs from that found in all the western outcrops, being localized in the Early Langhian, highest MNN5a subzone.

The absence of the MAR1-MAR3 members (Figure 2) implies that, during the entire Burdigalian-Early Langhian time span, the Marnoso Arenacea Fm did not deposit in this outer sector of the foredeep.

Actually, in the "Contessa" section (Figure 1), the homonym key-layer is placed nearly $105 \mathrm{~m}$ above the base of the MAR (Figure 2 and Figure S5), whereas it was drilled in the Mt Civitello well (location in Figure 1, Log available at: https:/ /www.videpi.com/videpi/ pozzi/dettaglio.asp?cod=3896; accessed on 10 February 2021) at least $~ 700 \mathrm{~m}$ above. 
The significant reduction of thickness of the pre-Contessa turbidite succession passing from the Pietralunga to the Gubbio Units occurs quite abruptly, straddling the Gubbio normal fault, and can be explained by its synsedimentary activity during BurdigalianLanghian times.

The interpretation of seismic reflection data by [70] confirms this hypothesis, showing that the Langhian terms of the Pietralunga Unit display an eastward-thickening wedgeshape geometry that is compatible with a growth on the Gubbio fault.

The hypothesis of an early structuring of the Gubbio anticline suggested in [12] could also explain the absence of the lower Langhian Marnoso Arenacea in this area. However, even if it cannot be ruled out a priori, we note that it does not explain the eastwardthickening of the succession highlighted by [70], west of the Gubbio fault.

A further significant feature, which differentiates the Gubbio succession from the more internal ones, is the absence of olistostromic bodies at all stratigraphic levels.

The lateral continuity of the Serravallian terms from the Pietralunga to the Gubbio units (including the related marker beds) leads us to exclude that the lack of olistostromes was due, in that time, to a subdivision of the foredeep into several smaller basins. More reasonably, it was caused by the emplacement mechanism of the olistostromes that, moving by sliding processes on a tectonically unstable slope, could not reach the outermost areas of the basin.

Finally, our biostratigraphic data do not confirm the occurrence of the Tortonian in the highest part of the succession, as already suggested in [12,69].

\subsection{Mt Vicino Unit}

The Mt Vicino Unit, which is the easternmost unit of the Umbria pre-Apennine, is located just at the back of the present carbonate chain. In this area the upper boundary of the Schlier Fm was dated to the Early Serravallian and the MAR Fm to the Early Serravallian-Early Tortonian (section Bf, Figure 1) [26,71].

During the uppermost part of Early Tortonian and the lower part of the Middle Tortonian, the turbidite flows continued to affect only a residual furrow east of the Gubbio structure, leading to the deposition of the Mt Vicino Fm [72,73].

The M. Vicino Fm consists of a 600 to $1400 \mathrm{~m}$ thick turbidite succession in which, from the bottom, the following facies associations have been recognized: (i) thin-bedded pelite alternating with subordinate thin to medium bedded arenites, (ii) middle to thickbedded arenaceous-pelitic turbidites, (iii) medium to thick-bedded arenites and bioclastic hybrid arenites.

The Mt Vicino Fm reaches its maximum thickness, of a few hundred meters, in the axial zone of the narrow depression which also corresponds to the core of the Serra Maggio syncline, suggesting that the latter was already in an advanced stage of structuring during sedimentation.

In other words, as proposed by [69], the Mt Vicino Fm deposited when the innermost folds of the Apennines were already growing, marking the late evolution of the MAR foredeep into the wedge-top basin stage.

Such a suggestion is confirmed by the occurrence, at intermediate stratigraphic levels within the succession, of slumped layers and coarse-grained poorly cemented turbiditic sandstones, showing Apennine provenance and both NW and SE paleocurrents [72,73].

\section{Reconstructed Timing of Deformations}

In the following, we reconstruct the timing of the main tectono-sedimentary stages and events which can be inferred based on the sedimentary evolution of the Marnoso Arenacea basin, described in the previous section.

Such stages, graphically schematized in the steps of Figures 5 and 6, document the setting, evolution, and progressive tectonization of the Umbria foreland basin system during the Miocene. Their temporal constraint is provided by the high-resolution biostratigraphic 
analysis performed on all the 24 studied sections, scattered throughout the entire northern Umbria pre-Apennines.

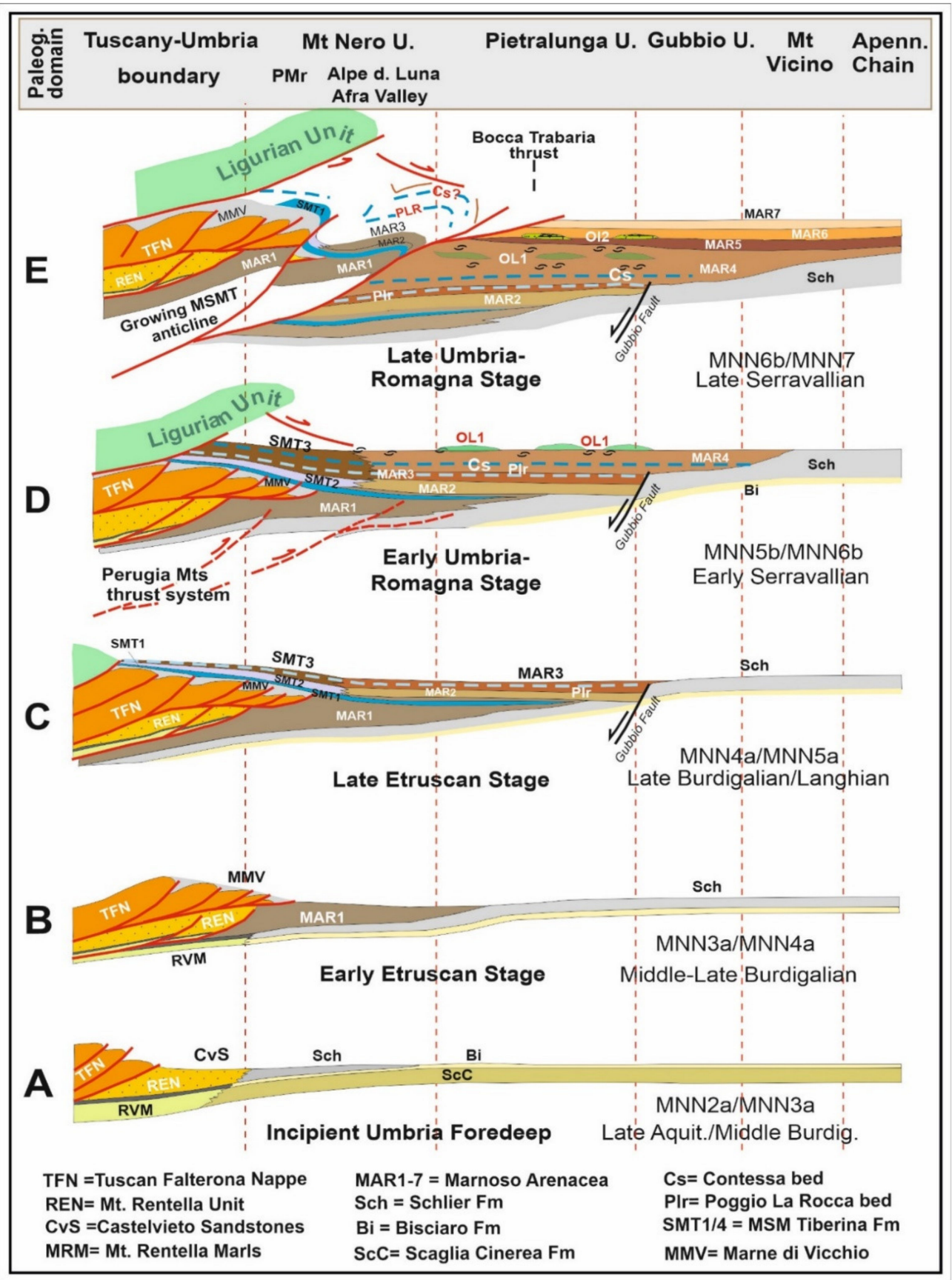

Figure 5. Exemplified tectono-sedimentary evolution of the Umbria pre-Apennines foreland basin system, during the Early and Middle Miocene; the stages, referred to the biozonation scheme proposed by [35-37] synthesized in Figure 2, are: (A) Incipient foredeep, (B) early Etruscan; (C) late Etruscan; (D) early Umbria-Romagna, and (E) late Umria Romagna stages (detail in the text; n.b.: sections are schematic and not in scale).

\subsection{Incipient Umbria Foredeep (Aquitanian-Burdigalian Boundary; MNN2a-MNN3a} Nannofossil Biozones)

The beginning of the regional subsidence related to the embryonic stage of the Umbria foredeep can be identified in the passage from hemipelagic (cherty marls of $\mathrm{Mt}$ Sperello) to turbidite deposition (Castelvieto-Montagnaccia Sandstones), within the REN Unit (Figures 5A and 6). At this stage the Apennine tectonic pile bounding the basin to the 
west included the Falterona Nappe, passively carrying the Liguride l.s. units and some wedge-top basins in which piggyback deposition took place (Celle Sandstones and Vicchio Marls, [7,74].

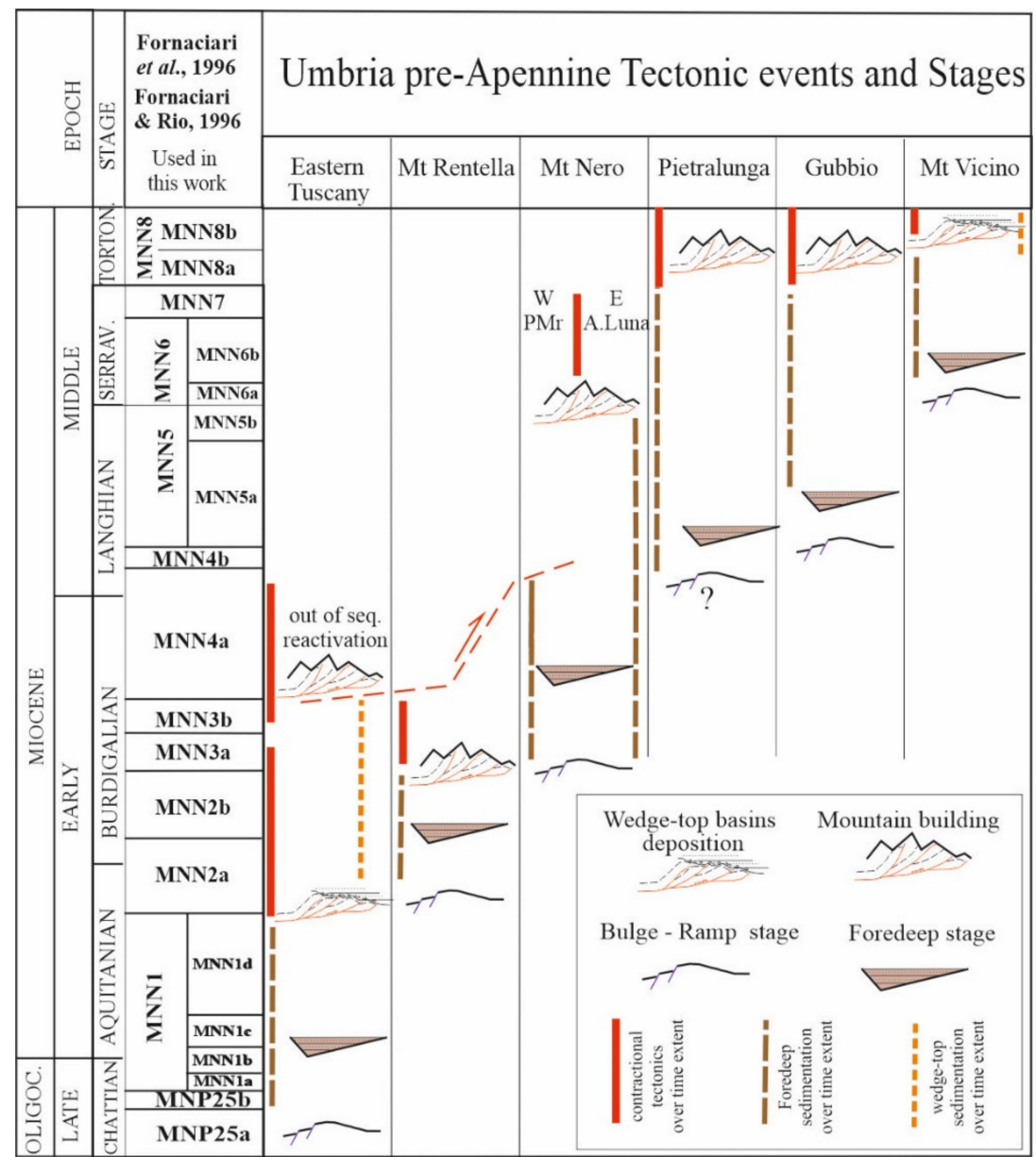

Figure 6. High-resolution timing of sedimentary and tectonic events (referred to the biochronostratigraphic scheme of Figure 2) recognized in each of the Units of the Umbria-pre-Apennines (detailed explanations in the text). The scheme is inspired by that proposed for the central Apennines by [6].

During the uppermost MNN2b-MNN3a zones (Middle Burdigalian), the REN Unit was affected by contractional deformations and progressively accreted into the orogen.

\subsection{Early Etruscan Stage (Middle-Late Burdigalian; MNN3a-MNN4a Nannofossil Biozones)}

The eastward migration of the orogenic wedge led to the setup of the Etruscan depocenter of the foredeep, in which the Mt Nero succession settled down (Figure 5B).

Up to the earlier Langhian, turbidite sedimentation affected exclusively this westernmost sector of the Umbria domain.

This inference is suggested by the stratigraphy of the Civitello1 borehole (Figures 1 and $4 a$, https: / / www.videpi.com/videpi/pozzi/dettaglio.asp?cod=3896; accessed on 10 February 2021), in which the base of the MAR of the Pietralunga Unit was attributed to an unspecified "Langhian"; moreover, the lithological descriptions of these lowermost turbidites show no facies affinity with the MAR1 and MAR2 members of Mt Nero Unit.

During the MNN3b-MNN4a (p.p.) interval, the Falterona Nappe underwent an outof-sequence reactivation (Figures 5B and 6) and, after overtaking the deformed REN unit, arrived at the west side of the foredeep and covered its westernmost sector, interrupting the sedimentation. 
At the beginning of Late Burdigalian (lower part of the MNN4a zone), its leadingedge can reasonably be thought to have reached its present location. This latter assertion is corroborated by the reciprocal consistency of the following points: (i) the topmost beds of MAR1, sampled just below the Falterona thrust in the Perugia Mts ridge (Monestevole = Mn section in Figure 1 and Figure S2, [18]), provided a MNN4a age, (ii) this same age was determined in the lowermost strata of the M. S. Maria Tiberina Fm, which has been proven to seal the front of the Tuscan allochthon in the Mt Cedrone area [21,27] (Figure S3), and (iii) the lacking evidence, in the younger and more eastern MAR of the Mt Nero Unit, of any signal of subsequent reactivation of the allochthon front.

\subsection{Late Etruscan Stage (Late Burdigalian-Late Langhian; MNN4a-MNN5a/b Nannofossil Biozones)}

This stage corresponds to the time which followed the emplacement of the Tuscan allochthon and pre-dates the nucleation of the major contractional structures within the western Umbria carbonates. During such an interval, most of the turbidite flows sedimented in the outer sector of the basin, giving rise to the upper MAR1 and the following MAR2 and MAR3 mrs.

Further west, in the wedge-top structural position, and also above the slope connecting the chain front with the foredeep depocenter (Figure 5C) Apennine-supplied low- and high-density turbidites, slumped bodies and pelite mud drapes continued to deposit (SMT3 and SMT4 mrs of the M.S. Maria Tiberina Fm).

No reliable data allows us to constrain the transversal extent of the foredeep in this stage beeing the lateral continuity of the Langhian succession not strictly constrained.

Nevertheless, the aforementioned stratigraphy of the Mt Civitello1 well indicates that, during the Langhian, the depocenter of the basin included the whole Mt Nero and part of the Pietralunga Units.

We can exclude with certainty that, during this stage, the MAR deposited east of the area where the Gubbio and Mt Subasio anticlines are presently located. This area was placed, up to the Early Langhian, in the peripheral bulge of the MAR foredeep, and the sedimentation of the Schlier Fm was still going on (Figures 5C and 6).

\subsection{Early Umbria-Romagna Stage (Late Langhian-Early Serravallian; MNN5b-MNN6b Nannofossil Biozones)}

We refer to this stage as "Umbria-Romagna" because our stratigraphic data, compared with the literature data collected over the past decades [3,9-13], undoubtedly demonstrates that a single and undivided foredeep developed in front of the Early Miocene northern paleo-Apennines.

The main argument supporting this inference is the lateral continuity of several keylayers over the entire MAR of the Umbria and Romagna area. These layers include the Contessa mega-bed, tens of "Colombina type" calcarenites, and some other noticeable arenite beds (Figure 3, Figures S4 and S5) $[3,9,25,66]$.

During this stage, which was characterized by quite stationary sedimentary conditions, the depocenter of the foredeep was localized in correspondence to the present Pietralunga Unit, whereas its eastern side extended to the Gubbio zone (Figures 5D and 6).

In other words, at least since the MNN5b zone, the MAR Fm was settling, with fairly uniform thickness, into a single wide basin.

The peripheral bulge was shifted to the Mt Vicino and the inner chain areas, where up to the MNN6a-(6b?) zone, the deposition of the Schlier ramp-muds persisted (Figures 3, $5 \mathrm{D}, 6$ and S6).

Orogenic contraction began to affect the older and more internal succession deposited during the Etruscan stage.

The onset of thrusting and, in particular, the growth of the Mt Cedrone anticline (see geological section of Figure S3) has been referred by [21] to the Early Serravallian (MNN6a subzone). 
Actually, the sudden fining-upward evolution of the M. S. Maria Tiberina Fm and the concurrent shallowing of the seafloor [27] may be interpreted as the first sign of ongoing compression at shallow crustal levels.

Uplift processes appear to have involved the entire western sector of the basin since the very Early Serravallian, as no turbidites younger than Late Langhian (MNN5b zone) have ever been detected at the top of the Mt Nero Unit.

As better explained in the following Section 5, we hypothesize that this regional-scale uplift is the shallow effect of the activation of the regional thrust fault displacing the Permo-Triassic basement in the subsurface of the Perugia Mts ridge [75-77].

\subsection{Late Umbria-Romagna Stage (Middle-Late Serravallian; MNN6b-MNN7)}

We place the beginning of this stage, in correspondence with the earliest involvement of the Serravallian MAR, in the orogenic deformations.

In particular, we interpret the emplacement of the Lame-Castiglione olistostrome (topmost MNN6b biozone) as evidence that the front of the chain, which had now extended to the completely detached Mt Nero Unit, was thrusted over the inner Pietralunga succession (Figure 5E). The inner part of this latter Unit was subsequently detached from the underlying Meso-Cenozoic carbonates and, at least since the earlier MNN7 biozone, was progressively shortened "in-sequence". Due to such progressive deformation, during the upper MNN7 biozone the width of the foredeep underwent a severe reduction and, as a consequence, the higher stratigraphic members of the succession (MAR6-MAR $7 \mathrm{mrs)}$ deposited only in the central-east part of the basin (Figure 5E).

The end of this stage can be located straddling the Serravallian-Tortonian boundary (top of MNN7 biozone), as we have not found Upper Miocene deposits in the Pietralunga and Gubbio successions (Figure 6 and Figure S6).

\subsection{Wedge-Top and Accretion Stage (Early-Middle Tortonian; MNN8-MNN9)}

At the beginning of the Late Miocene, the Langhian-Serravallian successions of both the Pietralunga and Gubbio Units were diffusely affected by contractional tectonics, giving rise to structures of variable scale: (i) regional macro-folds affecting the underlying MesoCenozoic carbonates (Figure 4), (ii) low-wavelength folds (some hundred meters to 1-2 km wide), detached at the Schlier Fm (Figure 4), and (iii) mesoscopic folds nucleated above local intra-formational decollements.

In the easternmost sector of the pre-Apennine, the growth of the Gubbio and $\mathrm{Mt}$ Subasio anticlines further reduced the active part of the foredeep, which, during the earlier Tortonian, was restricted to the Mt Vicino-Serra Maggio trough (Figure 1). This area was the only one located west of the chain, which hosted the MAR sedimentation during the Tortonian.

Above the MAR, the Mt Vicino sandstone (upper part of the Early Tortonian) deposited unconformably.

Reasonably, at the end of Early Tortonian, the further eastward progression of the contractional front caused the Mt Vicino sheet to override the innermost Umbria-Marche anticlines (Scheggia-Mt Maggio anticlines), which, according to [78] were in their initial stages of growth.

\section{Discussion and Final Remarks}

The systematic litho- and bio-stratigraphic study of the Umbria turbidite successions allowed for the recognition of the main evolutionary stages of the Umbria pre-Apennines' foredeep and the definition of the tectonic events that have involved the Miocene foreland basin system in this sector of the orogen.

Based on such high-resolution tectono-stratigraphic history, schematized in the steps of Figure 5, we have elaborated a kinematic model which describes the distribution of the structural paleo-domain over time (Figure 7). 


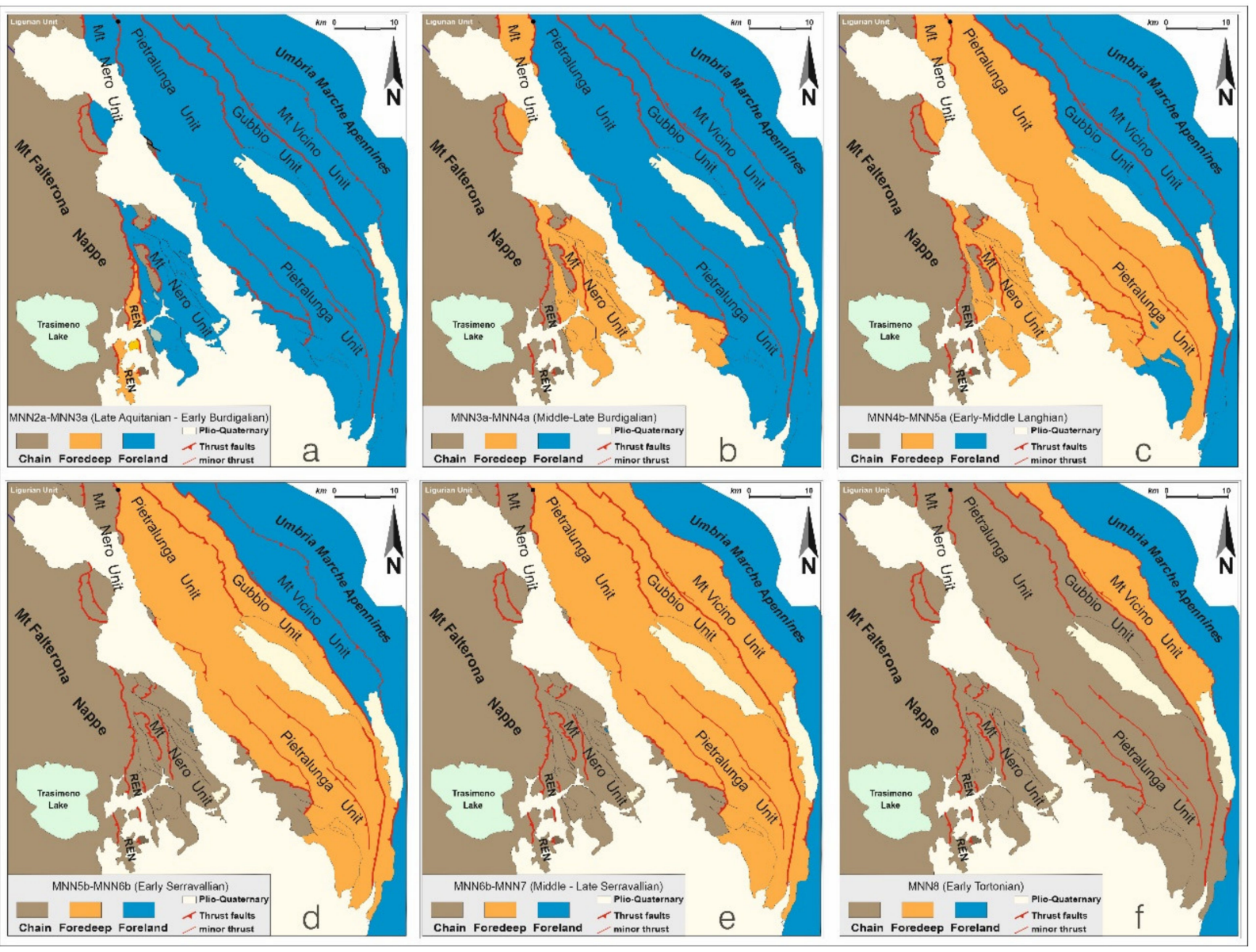

Figure 7. Distribution of the pre-Apennines structural paleo-domain, as inferred by the high-resolution tectono-stratigraphic timing summarized in Figure 6, during the: (a) Late Aquitanian-Early Burdigalian, (b) Middle-Late Burdigalian, (c) EarlyMiddle Langhian, (d) Early Serravallian, (e) Late Serravallian; (f) Early Tortonian. Note that the migrating paleo-domains are shown by the brown, orange, and blue colors and that the thrust faults refer to the present configuration, taken from Figure 1.

A first fundamental achievement of our reconstruction was the precise definition of the age of emplacement of the thrust-stack bounding west of the foredeep, which, at the end of the Aquitanian, included the Tuscan Falterona Nappe and the overlying allochthon units of Ligurian (l.s.) pertinence.

The over-thrusting of such tectonic pile above the Umbria domain is bracketed between the very Early Burdigalian and the Late Burdigalian and was articulated in two distinct steps: (a) "in-sequence" thrusting above the REN, during the MNN2b-MNN3a zones [15], and (b) "out-of-sequence" thrusting above the MAR, after overtaking the REN, which was, in turn, tectonically superimposed on the MAR of the Mt Nero Unit (Figure 6-Eastern Tuscany column- and Figure 7).

The out-of-sequence phase of the Falterona Nappe had not been previously recognized in Umbria and deserves to be verified in other sectors of the chain, e.g., in the TuscanEmilian Apennines, to understand if it must be considered a significant event on the geodynamic scale.

The eastward advancement of the Nappe, in Middle-Late Burdigalian times, progressively narrowed the Umbria foredeep of the early Etruscan stage and interrupted the sedimentation in its western sector $[7,18]$. The reduction of the basin-width, resulting in a lower availability of the accommodation space for the incoming gravity flows, might explain the increase in the average thickness of turbidite beds, observed at the passage from the lower member (MAR1-MNN3a-MNN4a biozones) to the intermediate one (MAR2 $\mathrm{mr}-\mathrm{MNN} 4 \mathrm{~b}-\mathrm{MNN} 5 \mathrm{a}$ biozones) of the Mt Nero Unit (Figure S2). Such an increase is consis- 
tent with a sharp change in the foredeep physiography that, during the late Etruscan stage, evolved from an open submarine plain to a strongly subsiding and transversely confined basin. In this regard, we must also consider that, during the aforementioned stages, the foredeep basin did not reach its maximum W-E extent, being delimited eastward by a set of west-dipping sinsedimentary normal faults that offset the foreland ramp.

Although the influence of foreland extensional faults on the MAR sedimentation is poorly investigated, the Gubbio normal fault seems to have played a significant role [70], producing a sharp uplift of the peripheral bulge that was located, in Early-Middle Langhian times, in its footwall block (Figure 7c).

After the emplacement of the allochthon units, the Umbria domain appears to have experienced an interval with absent or scarce deformation, at least from the Middle Burdigalian to the Early Serravallian (MNN4b-MNN6a biozones) - that is, for most of the Early Umbria-Romagna stage (Figure $7 \mathrm{~b}, \mathrm{c}$ ). Such a $\sim 3.5$ ma-long standstill can be bracketed between the time at which the front of the Falterona Nappe was sealed by the sedimentation of the M. S. Maria Tiberina Fm (lower MNN4a zone) and the first clear evidence of compression and uplift affecting the western Umbria carbonate multilayer (uppermost MNN6a zone).

We point out that the corresponding time interval, spanning from $\sim 17$ to $\sim 13.5 \mathrm{Ma}$, matches the transition between the collisional and post-collisional stages of the Apennine orogenesis [79-83]. The latter, which is still in progress, is associated with the Tyrrhenian rifting and is characterized by the eastward migration of two coupled-sub-parallel and synchronous tectonic belts causing contraction at the front and extension at the rear of the chain.

The evidence of a break in the shift of compressive deformation toward the foreland indicates that the passage between these two stages did not occur with continuity, at least in the more peripheral zone of the orogen.

In such a zone, the change in the geodynamic regime seems not to have produced significant tectonic manifestations during the time required for the new stress-field to propagate outside the collisional suture.

We are aware that such a hypothesis is preliminary and highly speculative. Anyhow, we want to stress that having highlighted such a protracted stasis in the orogenic deformations is an unexpected result, worthy of being further investigated, to verify its consistency also in other areas of the Middle Miocene Apennine front.

We refer the compression of the western Umbria domain (Figure 7d) to the Early Serravallian (MNN6a-MNN6b biozones), as suggested by the shallowing-upward trend of the topmost M. S. Maria Tiberina Fm and by the subsequent interruption of its sedimentation [21,27].

During this time interval, a major thrust fault nucleated within the Permian-Triassic basement [51,75-77]. It displaced the Meso-Cenozoic Multilayer of the Perugia Mts ridge and, branching at shallower structural levels, gave rise to an imbricate fan and associated folds affecting the MAR.

We identify the main surface expression of this regional thrust in the frontal thrust of the Mt Nero Unit, which is well-exposed in the Alpe della Luna (Afra Valley) and has been recognized to discontinuously crop out also even further south, in the hydrographic left of the Tiber (Figures 1 and 4 ).

Considering the amount of the associated displacement and the considerable continuity of this structure, all along the entire central Umbria (Figure 1), we hypothesize its possible correlation with the "Mandriacce Line", described in the Marnoso Arenacea Romagnola [84], which causes the systematic superposition of Langhian terms above Serravallian ones.

According to our reconstruction, thrusting in western Umbria went on until the Late Serravallian, as shown by the timing of emplacement of the upper olistostromic slices (earlier MNN7a zones) within the MAR of the Pietralunga Unit (Figures 5D,E and 7e). 
The few public subsurface data, available in the area comprised between the Tiber Valley and the Umbria-Marche chain, highlights that the contractional deformations affecting the Pietralunga MAR are arranged in a shallow imbricate whose basal decollement is localized at the top of the Meso-Cenozoic Carbonate multilayer (Figure 4a,b).

The geometry of such a thrust system, joined to the observation that the uppermost members of the succession (MAR5-7) occur only in the easternmost sector of the Pietralunga Unit, supports the inference of an "in-sequence" thrusting, within this unit, during the very Late Serravallian-Early Tortonian (uppermost MNN7b-MNN8 biozones, Figures 5 and 6).

However, it should be noted that such argument is not conclusive, as it cannot be excluded that the complete absence of such members, in the innermost areas, might also be due to widespread erosion, rather than their non-deposition.

Just after the beginning of the Early Tortonian, the Umbria foredeep was entirely undergoing compression, whereas the origin of the Serra Maggio syncline can be confidently placed in the Late Tortonian, taking into account the piggyback sedimentation of the $\mathrm{Mt}$ Vicino sandstones.

Subsequently, the so-called "intra-Messinian" phase [22,72] split the previously unitary foredeep in several minor basins interposed to the rising Umbria-Marche anticlines. Inside them, a terrigenous-evaporitic sedimentation occurred up to the earlier Pliocene.

At the end of this latter period, after the uplift and accretion into the chain of such residual elongated furrows, the tectono-sedimentary history of the Umbria foreland basin system was over.

Supplementary Materials: The following are available online at https:/ /www.mdpi.com/2076-326 3/11/2/97/s1, Figures S1-S6.

Author Contributions: F.B. and L.L. conceived the work. F.B. and D.C. performed the fieldwork. L.L. carried out the nannofossil analyses and the biostratigraphic determinations. F.B. wrote the manuscript. D.C. and F.B. interpreted the seismic lines and prepared the figures. D.C. geo-referenced the maps and carried out the final review of the manuscript. All authors have read and agreed to the published version of the manuscript.

Funding: This work was funded by DiSPUTer Departmental Research grants 2020 (Resp. F. Brozzetti).

Acknowledgments: We thank two anonymous referees for the constructive comments, that have been useful for improving the manuscript.

Software Used in This Work: Field survey was partly performed through Fieldmove software $\left(\right.$ Move $^{\mathrm{TM}}$, produced by Midland Valley Exploration Ltd. 2018 Glasgow, and Petroleum Experts Edinburgh, Scotland UK-https:/ / www.petex.com/products/move-suite/digital-field-mapping/, accessed on 10 February 2021) installed on an Apple iPad-Pro. The newly acquired data were managed in a GIS database elaborated through ArcGIS v.10.8. Figure 1 was created using ArcGIS v.10.8 (http:/ / desktop.arcgis.com; accessed on 10 February 2021). Figures 2-6 and all the supplementary figures were drawn using CorelDRAW graphics suite 2020 (https: / www.coreldraw.com; accessed on 10 February 2021). The interpretation of seismic lines and their conversion to depth (Figure 4) were carried out with the Move suite software 2019.1.8 (https:/ /www.petex.com/products/move-suite/; accessed on 10 February 2021), in particular using the 2D depth conversion tool. Microsoft Excel was used to elaborate the distribution diagrams for the marker species of nannofossils, placed alongside the stratigraphic columns of Figures S2, S4 and S5.

Conflicts of Interest: The authors declare no conflict of interests.

\section{References}

1. DeCelles, P.G.; Giles, K.A. Foreland basin systems. Basin Res. 1996, 8, 105-123. [CrossRef]

2. Ori, G.G.; Friend, P.F. Sedimentary basins formed and carried piggyback on active thrust sheets. Geology 1984, 12, 475-478. [CrossRef]

3. Argnani, A.; Ricci Lucchi, F.R. Tertiary Silicoclastic Turbidite Systems of the Northern Apennines. In Anatomy of an Orogen: The Apennines and Adjacent Mediterranean Basins; Vai, G.B., Martini, I.P., Eds.; Kluver Academic Publishers: Amsterdam, The Netherlands, 2001; pp. 327-350. [CrossRef] 
4. Patacca, E.; Scandone, P.; Bellatalla, M.; Perilli, N.; Santini, U. La zona di giunzione tra l'arco appenninico settentrionale e l'arco appenninico meridionale nell'Abruzzo e nel Molise. St. Geol. Camerti 1991, 417-441. [CrossRef]

5. Cipollari, P.; Cosentino, D.; Esu, D.; Girotti, O.; Gliozzi, E.; Praturlon, A. Thrust-top lacustrine-lagoonal basin development in accretionary wedges: Late Messinian (Lago-Mare) episode in the central Apennines (Italy). Palaeogeogr. Palaeocl. 1999, 151, 149-166. [CrossRef]

6. Cosentino, D.; Cipollari, P.; Marsili, P.; Scrocca, D. Geology of the central Apennines: A regional review. J. Virtual Explor. 2010, 36, 1-37. [CrossRef]

7. Brozzetti, F.; Boncio, P.; Pialli, G. Early-Middle Miocene evolution of the Tuscan Nappe-Western Umbria foredeep system: Insights from stratigraphy and structural analysis. Boll. Soc. Geol. It. Vol. Spec. 2002, 1, 319-331.

8. Mutti, E.; Tinterri, R.; Benevelli, G.; di Biase, D.; Cavanna, G. Deltaic, mixed and turbidite sedimentation of ancient foreland basins. Mar. Petrol. Geol. 2003, 20, 733-755. [CrossRef]

9. Ricci Lucchi, F. The Oligocene to Recent foreland basins of the northern Apennines. Spec. Publ. Int. Ass. Sediment. 1986, 8, 105-139.

10. Ten Haaf, E.; Van Wamel, W.A. Nappes of the Alta Romagna. In Fixism, Mobilism or Relativism: Van Bemmelen's Search for Harmony; Van Der Linden, W.J.M., Ed.; Royal Geological and Mining Society of The Netherlands: Utrecht, The Netherlands, 1979; Volume 58, pp. 145-152.

11. De Feyter, A.J. The structure of the Northern Umbria Apennines, Italy. Geol. Mijnbouw 1982, 16, 183-189.

12. Menichetti, M.; Pialli, G. Geologia strutturale del Preappennino umbro tra i Monti di Gubbio e la catena del M. Petrano-M. Cucco (Appennino Umbro-Marchigiano). Mem. Soc. Geol. Ital. 1986, 35, 371-388.

13. Conti, P.; Cornamusini, G.; Carmignani, L.; Pirro, A.; Pizziolo, M.; Daniele, G.; Lavorini, G.; Motti, A.; Natali, N.; Bettucci, C. Carta Geologica delle Regioni Emilia-Romagna, Marche, Toscana e Umbria. Scala 1:250000. 2019. Available online: https://www.geologicalmap.it/pdf.html (accessed on 10 February 2021).

14. Conti, P.; Cornamusini, G.; Carmignani, L. Note Illustrative della Carta Geologica delle Regioni Emilia-Romagna, Marche, Toscana e Umbria. Scala 1:250000. 2019. Available online: https:/ / www.geological-map.it/expl.html (accessed on 10 February 2021).

15. Brozzetti, F.; Luchetti, L.; Pialli, G. La successione di M. Rentella (Umbria occidentale): Biostratigrafia a nannofossili calcarei ed ipotesi per un inquadramento tettonico regionale. Boll. Soc. Geol. It. 2000, 119, 407-422.

16. Menichetti, M.; De Feyter, A.; Corsi, M. CROP03-Il tratto Val Tiberina-Mare Adriatico: Sezione Geologica e caratterizzazione tettonico-sedimentaria delle avanfosse della zona Umbro-Marchigiano-Romagnola. Studi Geol. Cam. 1991, 1, $279-293$.

17. Damiani, A.V.; Pannuzzi, L.; Pialli, G. Osservazioni geologiche nelle aree comprese fra i massicci perugini ed i rilievi di Gubbio. Giorn. Geol. 1983, 45, 127-150.

18. Luchetti, L. Biostratigrafia a nannofossili calcarei delle successioni torbiditiche mioceniche dell'area di M. Acuto e di M. Corona (Umbria nord-occidentale, Italia centrale). Boll. Soc. Geol. It. 1998, 117, 333-335.

19. Zattin, M.; Zuffa, G.G. Unravelling the source rocks of Late Eocene-Miocene orogenic wedge and foredeep arenites of the northern Apennines and southern Alps. Boll. Soc. Geol. It. 2004, 123, 67-76.

20. Pialli, G.; Plesi, G.; Damiani, V.A.; Brozzetti, F. Note Illustrative della Carta Geologica d'Italia alla Scala 1:50.000; Foglio 289—Città di Castello. 2009. Available online: https://www.isprambiente.gov.it/Media/carg/note_illustrative/289_Citta_di_Castello.pdf (accessed on 10 February 2021).

21. Brozzetti, F. The Umbria Preapennines in the Monte Santa Maria Tiberina area: A new geological map with stratigraphic and structural notes. Boll. Soc. Geol. It. 2007, 126, 511-529.

22. Barchi, M.R. The Neogene-Quaternary evolution of the Northern Apennines: Crustal structure, style of deformation and seismicity. J. Virtual Explor. 2010, 36, 11. [CrossRef]

23. Guerrera, F.; Tramontana, M.; Donatelli, U.; Serrano, F. Space/time tectono-sedimentary evolution of the Umbria-RomagnaMarche Miocene Basin (Northern Apennines, Italy): A foredeep model. Swiss J. Geosci. 2012, 105, 325-341. [CrossRef]

24. Pialli, G. Osservazioni geologiche sulle formazioni flyschoidi di Castiglione Aldobrandi (foglio 123 IV NW). Mem. Soc. Geol. It. 1966, 5, 365-386.

25. Ricci Lucchi, F; Pialli, G. Apporti secondari nella marnoso arenacea: 1. torbiditi di conoide e di pianura sottomarina ad est-nordest di Perugia. Boll. Soc. Geol. It. 1973, 92, 669-712.

26. Luchetti, L. Stratigrafia a Nannofossili Calcarei della Marnoso Arenacea dell'Umbria Settentrionale Fra il Fronte Dell'unità Falterona e la Dorsale Eugubina. Ph.D. Thesis, Università di Perugia, Perugia, Italy, 1997; 118p.

27. Luchetti, L.; Brozzetti, F.; Nini, C.; Nocchi, M.; Rettori, R. Lithostratigraphy, integrated biostratigraphy and paleoenvironmental analysis of the Monte Santa Maria Tiberina Miocenic succession (Umbria-central Italy). Boll. Soc. Geol. It. 2002, 121, 589-602.

28. Centamore, E.; Chiocchini, U. Le unità torbiditiche della Marnoso Arenacea nell'alta Valle del Tevere. Stud. Geol. Camerti 1985, 10, 37-59.

29. Chiocchini, U.; Chiocchini, M.; Cipriani, N.; Torricini, F. Petrografia delle unità torbiditiche della Marnoso-arenacea nell'alta Valle Tiberina. Mem. Soc. Geol. It. 1986, 35, 57-73.

30. Servizio Geologico d'Italia. Carta Geologica d'Italia alla Scala 1:50.000, Foglio 289 Città di Castello. 2010. Available online: http://www.isprambiente.gov.it/Media/carg/289_CITTA_CASTELLO/Foglio.html (accessed on 10 February 2021).

31. Gandolfi, G.; Paganelli, L.; Zuffa, G.G. Petrology and dispersal pattern in the Marnoso Arenacea formation (Miocene, northern Apennines). J. Sediment. Res. 1983, 53, 493-507.

32. Mutti, E. Turbidite sandstones; San Donato Milanese; Agip-Istituto di Geologia, Università di Parma: Parma, Italy, 1992; 275p. 
33. Thierstein, H.R.; Geitzenauer, K.R.; Molfino, B. Global synchroneity of late Quaternary coccolith datum levels: Validation by oxygen isotopes. Geol. Soc. Am. Bull. 1977, 5, 400-404. [CrossRef]

34. Backman, J. Miocene-Pliocene nannofossils and sedimentation rates in the Hatton-Rockall Basin, NE Atlantic Ocean. Stockh. Contrib. Geol. 1980, 36, 1-91.

35. Rio, D.; Fornaciari, E.; Raffi, I. Late Oligocene through Early Pleistocene calcareous nannofossils distribution patterns in the western Mediterranean. Proc. Ocean. Drill. Program. Sci. Res. 1990, 107, 175-235.

36. Fornaciari, E.; Rio, D. Latest Oligocene to Early Miocene quantitative calcareous nannofossils biostratigraphy in the mediterranean region. Mycropaleontology 1996, 42, 1-36. [CrossRef]

37. Fornaciari, E.; Di Stefano, A.; Rio, D.; Negri, A. Middle Miocene quantitative calcareous nannofossils biostratigraphy in the mediterranean region. Micropoaleontology 1996, 42, 37-63. [CrossRef]

38. Martini, E. Standard Tertiary and Quaternary calcareous nannoplankton zonation. In Proceedings of the Second International Conference on Planktonic Microfossils, Rome, Italy, 1971; Farinacci, A., Ed.; Volume 2, pp. 739-785. Available online: https: / / onlinelibrary.wiley.com/doi/epdf/10.1002/iroh.19720570511 (accessed on 19 February 2021).

39. Okada, H.; Bukry, D. Supplementary modification and introduction of code numbers to the low-latitude coccolith biostratigraphic zonation (Bukry 1973, 1975). Mar. Micropaleontol. 1980, 5, 321-325. [CrossRef]

40. Backman, J.; Raffi, I.; Rio, D.; Fornaciari, E.; Pälike, H. Biozonation and biochronology of Miocene through Pleistocene calcareous nannofossils from low and middle latitudes. Newslett. Stratigr. 2012, 45, 221-244. [CrossRef]

41. Raffi, I.; Agnini, C.; Backman, J.; Catanzariti, R.; Pälike, H. A Cenozoic calcareous nannofossil biozonation from low and middle latitudes: A synthesis. J. Nannoplankton Res. 2016, 36, 121-132.

42. Fabbrini, A.; Baldassini, N.; Caricchi, C.; Foresi, L.M.; Sagnotti, L.; Dinarès-Turell, J.; Di Stefano, A.; Lirer, F.; Menichetti, M.; Winkler, A.; et al. In search of the Burdigalian GSSP: New evidence from the Contessa Section (Italy). Ital. J. Geosci. 2019, 138, 274-295. [CrossRef]

43. Di Stefano, A.; Foresi, L.M.; Iaccarino, S.M.; Turco, E.; Amore, F.O.; Mazzei, R.; Morabito, S.; Salvatorini, G.; Aziz, H.A. Calcareous nannoplancton high-resolution bio-magnetostratigraphy for the Langhian of the Mediterranean area. Riv. Ital. Paleont. Stratigr. 2008, 114, 51-76.

44. Backman, J.; Shackleton, N.J. Quantitative bio chronology of Pliocene and early Pleistocene calcareous nannoplankton from the Atlantic, Indian and Pacific Oceans. Mar. Micropaleontol. 1983, 8, 141-170. [CrossRef]

45. Pujos, A. Late Eocene to Pleistocene medium-sized and small-sized "Reticulofenestrids". Abh. Geologischen Bundesanst. 1987, 39, 239-277.

46. Flores, J.A.; Sierro, F.J. Calcareous nannoflora and planktonic foraminifera in the Tortonian-Messinian boundary interval of East Atlantic DSDP sites and their relation to Spanish and Moroccan sections. In Nannofossils and Their Applications: Chichester; Crux, J.A., van Heck, S.E., Eds.; Ellis Horwood: Chichester, UK, 1989; pp. 249-266.

47. Young, J.R. Neogene. In Calcareous Nannofossil Biostratigraphy; Bown, P.R., Ed.; Kluwer Academic: London, UK, 1998 ; pp. 225-265.

48. Takayama, T. Notes on Neogene calcareous nannofossil biostratigraphy of the Ontong Java Plateau and size variations of Reticulofenestra coccoliths. In Proceedings of the ODP, Scientific Results 130 (Ocean Drilling Program), College Station, TX, USA, 1993; Berger, W.H., Kroenke, L.W., Mayer, L.A., Eds.; pp. 179-229. Available online: http://www-odp.tamu.edu/publications/13 0_SR/VOLUME/CHAPTERS/sr130_11.pdf (accessed on 19 February 2021). [CrossRef]

49. Kameo, K.; Sato, T.; Takayama, T. Late Pliocene calcareous nannofossil datums and biohorozons. In 5 th INA Conference in Salamanca Proceedings; Flores, J.A., Sierro, F.J., Eds.; Universidad de Salamanca Press: Salamanca, Spain, $1995 ;$ pp. 87-98.

50. Raffi, I.; Rio, D. Calcareous nannofossil biostratigraphy of DSDP Site 132, Leg 13 (Tyrrhenian Sea-Western Mediterranean). Riv. It. Paleontol. Stratigr. 1979, 85, 127-172.

51. Mirabella, F.; Brozzetti, F.; Lupattelli, A.; Barchi, M. Tectonic evolution of a low-angle extensional fault system from restored cross-sections in the Northern Apennines (Italy). Tectonics 2011, 30, TC6002. [CrossRef]

52. Bucefalo Palliani, R.; Luchetti, L.; Nini, C.; Nocchi, M.; Rettori, R. Age and palaeoecological inferences of the upper Monte Falterona Sandstones Formation (Lonnano Member, Early Miocene), Northern Apennines. Giorn. Geologia 1997, 59, 143-168.

53. Servizio Geologico d'Italia. Carta Geologica d'Italia alla Scala 1:50.000, Foglio 310 Passignano sul Trasimeno. 2014. Available online: https:/ / www.isprambiente.gov.it/Media/carg/310_PASSIGNANO/Foglio.html (accessed on 10 February 2021).

54. Barchi, M.; Marroni, M. Note Illustrative della Carta Geologica d'Italia alla Scala 1:50.000; Foglio 310 Passignano sul Trasimeno. 2014. Available online: https://www.isprambiente.gov.it/Media/carg/note_illustrative/310_Passignano_sul_Trasimeno.pdf (accessed on 10 February 2021).

55. Barsella, M.; Boscherini, A.; Botti, F.; Marroni, M.; Meneghini, F.; Motti, A.; Palandri, S.; Pandolfi, L. Oligocene-Miocene foredeep deposits in the Lake Trasimeno area (Central Italy): Insights into the evolution of the Northern Apennines. Boll. Soc. Geol. It. 2009, 128, 341-352. [CrossRef]

56. Aruta, G.; Bruni, P.; Cipriani, N.; Pandeli, E. The siliciclastic turbidite sequences of the Tuscan Domain in the Val di Chiana-Val Tiberina area (Eastern Tuscany and North-Western Umbria). Mem. Soc. Geol. It. 1998, 52, 579-593.

57. Plesi, G.; Damiani, A.V.; Boscherini, A.; Martini, E.; Luchetti, L.; Palandri, S.; Rettori, R.; Tuscano, F.; Botti, F.; Daniele, G.; et al. Note Illustrative della Carta Geologica d'Italia alla Scala 1:50.000, F. 299 Umbertide. ISPRA-Rome. 2010. Available online: https://www.isprambiente.gov.it/Media/carg/note_illustrative/299_Umbertide.pdf (accessed on 10 February 2021). 
58. Costa, E.; Di Giulio, A.; Negri, A.; Plesi, G. CROP 03. Settore compreso tra Castiglion Fiorentino e Bocca Trabaria: Nuovi dati stratigrafici, petrografici e strutturali. Stud. Geol. Cam. 1991, 1, 217-234.

59. Andreozzi, M.; Di Giulio, A. Stratigraphy and petrography of the Mt. Cervarola Sandstone in the type area, Modena Province. Mem. Soc. Geol. It. 1994, 48, 351-360.

60. Servizio Geologico Nazionale. Carta Geologica d'Italia alla Scala 1:100.000; Foglio 130_Orvieto. Available online: http: / / sgi.isprambiente.it/geologia100k/mostra_foglio.aspx?numero_foglio=130 (accessed on 10 February 2021).

61. Signorini, R. Struttura dell'Appennino tra la Val Tiberina e l'Urbinate. Giorn. Geol. 1941, 15, 17-29.

62. D'Offizi, S.; Minelli, G.; Pialli, G. Foredeeps and thrust systems in the Northern Apennines. Boll. Geof. Teor. Appl. 1994, 36, 91-102.

63. Van Wamel, W.A.; Zwart, P.E. The structural geology and basin development of the Romagna-Umbrian zone (Upper Savio and Upper Bidente Valleys, N.Italy). Geol. Mijnb. 1990, 69, 53-68.

64. Delle Rose, M.; Guerrera, F.; Moretti, E.; Rusciadelli, G. Evoluzione del segmento interno dell'Avanfossa Appenninica durante il Miocene medio (spartiacque tosco-romagnolo). Giorn. Geol. 1990, 52, 135-158.

65. Delle Rose, M.; Guerrera, F.; Moretti, E.; Ruscadelli, G.; Corona, F. The Marnoso-Arenacea Fm. betweeen Bocca Trabaria and Campigna (Northern Apennines): Lithostratigraphy from Schlier to the Verghereto Marls Fms., in a new structural context. Giorn. Geol. 1991, 53, 131-145.

66. Ridolfi, A.; Luchetti, L.; Menichetti, M.; Negri, A.; Pialli, G. Use of key-bed in stratigraphical and structural analysis of the Marnoso Arenacea of the Assino Valley area (Northern Umbria pre-Apennines). Giorn. Geol. 1995, 57, 113-129.

67. Boscherini, A.; Nocchi, M.; Pialli, G. Geologia della Riva Etrusca del Tevere tra le confluenze del T. Niccone e del T. Nese. Rend. Acc. Sc. Fis. Nat. Soc. Naz. Napoli 1982, 48, 409-444.

68. Jacobacci, A.; Bergomi, C.; Centamore, E.; Malatesta, A.; Malferrari, N.; Martelli, G.; Pannuzzi, L.; Zattini, N. Note illustrative della Carta Geologica d'Italia alla scala 1: 100.000—Fogli 115 «Città di Castello»—122 «Perugia»—130 «Orvieto»; Generico: Salerno, Italy, 1970; p. 151.

69. De Feyter, A.J.; Molenaar, N.; Pialli, G.; Menichetti, M.; Veneri, F. Paleotectonic Significance of Gravity Displacement Structures in the Miocene Turbidite Series of the M Pollo Syncline (Umbro-Marchean Apennines, Italy). Geol. Mijnb. 1990, 69, 69-86.

70. Mirabella, F.; Ciaccio, M.; Barchi, M.; Merlini, S. The Gubbio normal fault (central Italy): Geometry, displacement distribution and tectonic evolution. J. Struct. Geol. 2004, 26, 2233-2249. [CrossRef]

71. Cantalamessa, G.; Centamore, E.; Chiocchini, U.; Micarelli, A.; Potetti, M.; Di Lorito, L. II Miocene delle Marche. In La Geologia delle Marche; Centamore, E., Deiana, G., Eds.; Università di Camerino, Dipartimento di Scienze della Terra: Camerino, Italy, 1986; pp. 35-55.

72. Centamore, E.; Chiocchini, U.; Cipriani, N.; Deiana, G.; Micarelli, A. Analisi dell'evoluzione tettonico-sedimentaria dei “bacini minori" torbiditici del Miocene medio-superiore nell'Appennino umbro-marchigiano e laziale-abruzzese: (5) risultati degli studi in corso. Mem. Soc. Geol. It. 1978, 18, 135-170.

73. Centamore, E.; Chiocchini, U.; Micarelli, A. Analisi dell'evoluzione sedimentaria dei "bacini minori" torbiditici del Miocene medio-superiore nell'Appennino umbro-marchigiano e laziale-abruzzese: (3) Le Arenarie di M. Vicino, un modello di conoide sottomarina affogata (Marche set tentrionali). Stud. Geol. Camerti 1977, 3, 7-56.

74. Plesi, G.; Luchetti, L.; Boscherini, A.; Botti, F.; Brozzetti, F.; Bucefalo Palliani, R.; Daniele, G.; Motti, A.; Nocchi, M.; Rettori, R. The Tuscan succession of high Tiber valley (F.289 Cittá di Castello): Biostratigraphic, petrographic and structural features, regional correlations. Boll. Soc. Geol. Ital. 2002, 121, 425-436.

75. Minelli, G.; Motti, A.; Pialli, G. Evoluzione tettonica dei Massicci Perugini; area di Monte Torrazzo. Mem. Soc. Geol. It. 1986, 35, 389-398.

76. Barchi, M.R.; De Feyter, A.; Magnani, M.B.; Minelli, G.; Pialli, G.; Sotera, B.M. The structural style of the Umbria-Marche fold and thrust belt. Mem. Soc. Geol. It. 1998, 52, 557-578.

77. Minelli, G.; Menichetti, M. Tectonic evolution of the Perugia massifs area (central Italy). Boll. Soc. Geol. Ital. 1990, 109, 445-453.

78. De Feyter, A.; Koopman, A.; Molenaar, N.; Van den Ende, C. Detachment tectonics and sedimentation, Umbro-Marchean Apennines, Italy. Boll. Soc. Geol. It. 1986, 105, 65-85.

79. Carmignani, L.; Decandia, F.A.; Disperati, L.; Fantozzi, P.L.; Lazzarotto, A.; Liotta, D.; Meccheri, M. Tertiary extensional tectonics in Tuscany (Northern Apenines, Italy). Tectonophysics 1994, 238, 295-315. [CrossRef]

80. Liotta, D.; Cernobori, L.; Nicolich, R. Restricted rifting and its coexistence with compressional structures: Results from the Crop03 traverse (Northern Apennines, Italy). Terra Nova 1998, 10, 16-20. [CrossRef]

81. Mattei, M.; Cipollari, P.; Cosentino, D.; Argentieri, A.; Rossetti, F.; Speranza, F.; Di Bella, L. The Miocene tectonosedimentary evolution of the Southern Tyrrhenian Sea: Stratigraphy, structural and paleomagnetic data from the onshore Amantea Basin (Calabrian Arc Italy). Basin Res. 2002, 14, 147-168. [CrossRef]

82. Milia, A.; Torrente, M.M. Early-stage rifting of the southern Tyrrhenian region: The Calabria-Sardinia breakup. J. Geodyn. 2014, 81, 17-29. [CrossRef]

83. Milia, A.; Valente, A.; Cavuoto, G.; Torrente, M.M. Miocene progressive forearc extension in the Central Mediterranean. Tectonophysics 2017, 710-711, 232-248. [CrossRef]

84. Farabegoli, E.; Benini, A.; Martelli, L.; Onorevoli, G.; Severi, P. Geologia dell'Appennino Romagnolo da Campigna a Cesenatico. Mem. Descr. Carta Geol. It. 1991, 46, 165-184. 